\title{
Engineering Planning Method and Control Modes for Debris Flow Disasters in Scenic Areas
}

\author{
Xing-Long Gong ${ }^{1,2,3}$, Xiao-Qing Chen ${ }^{1,2,3}$, Kun-Ting Chen ${ }^{4,5 *}$, Wan-Yu Zhao ${ }^{1}$ and \\ Jian-Gang Chen ${ }^{1}$
}

${ }^{1}$ Key Laboratory of Mountain Hazards and Earth Surface Processes, Institute of Mountain Hazards and Environment, Chinese Academy of Sciences, Chengdu, China, ${ }^{2}$ China-Pakistan Joint Research Center on Earth Sciences, CAS-HEC, Islamabad, Pakistan, ${ }^{3}$ University of Chinese Academy of Sciences, Beijing, China, ${ }^{4}$ Compound Disaster Prevention Research Center, General Research Service Center, National Pingtung University of Science and Technology, Pingtung, Taiwan, ${ }^{5}$ Department of Soil and Water Conservation, National Pingtung University of Science and Technology, Pingtung, Taiwan

Compared with debris flows in other areas, debris flows in scenic areas not only seriously threaten residents, tourists, roads, walkways, and other infrastructure, but also cause considerable damage to the landscapes and ecosystems of these areas. Extreme rainfall events in the future will increase the complexities and challenges involved in debris flow control in scenic areas. Currently, the systematic planning of the entire scenic area is not

OPEN ACCESS

Edited by:

Yih-Chin Tai,

National Cheng Kung University,

Taiwan

Reviewed by: Kana Nakatani,

Kyoto University, Japan Kuo-Lung Wang,

National Chi Nan University, Taiwan

*Correspondence: Kun-Ting Chen kuntingchen@mail.npust.edu.tw

\footnotetext{
Specialty section:

This article was submitted to Geohazards and Georisks, a section of the journal

Frontiers in Earth Science
}

Received: 20 May 2021 Accepted: 13 August 2021 Published: 24 September 2021

Citation: Gong $X-L$, Chen $X-Q$, Chen $K-T$, Zhao $W-Y$ and Chen J-G (2021) Engineering Planning Method and Control Modes for Debris Flow

Disasters in Scenic Areas.

Front. Earth Sci. 9:712403.

doi: 10.3389/feart.2021.712403 considered in the treatment of debris flows. It is not possible to realize the rapid planning of any debris flow gully control project in a scenic area and to quantify the volume of debris flow material retained by each engineering structure. Based on field investigations and data collected from debris flow control projects in gullies in Jiuzhaigou Valley, China, an engineering planning method for debris flow control projects in scenic areas is herein proposed, and the challenges confronting existing control projects in scenic areas are discussed. Moreover, based on the example of Jiuzhaigou Valley, corresponding control engineering schemes for debris flow gullies in Xiajijie Lake Gully, Zhuozhui Gully, Xuan Gully, Pingshitou Gully, and West-Zhuozhui Gully are formulated. Four control modes for debris flow disasters in scenic areas are proposed, namely, "blocking + deposit stopping," "deposit stopping," "blocking," and "drainage + deposit stopping," which provide a systematic control strategy for post-earthquake debris flow disaster management in Jiuzhaigou Valley and other similar scenic areas.

Keywords: engineering planning method, control mode, debris flow, scenic areas, climate change

\section{INTRODUCTION}

Debris flows are mixtures of sediment and water that flow down a slope under the influence of gravity. These disasters are widespread and commonplace in mountainous areas. Steep topography, abundant loose material, and concentrated rainfall are three important factors influencing debris flow formation. Numerous studies have attempted to elucidate the debris flow formation process based on rainfall thresholds and sediment supply conditions (Takahashi, 2007; Santi et al., 2008; Tang et al., 2012; Hungr et al., 2014; Zhang et al., 2014; Fan R. L. et al., 2018; Domènech et al., 2019). In particular, post-earthquake debris flows have been widely studied owing to their significant destructive power. In general, a devastating earthquake generates an adequate supply of sediment in the form of co-seismic collapses and landslides, which indirectly reduces the rainfall threshold 
required to trigger a debris flow (Tang et al., 2012; Ma et al., 2017); catastrophic debris flows can be triggered even by lowintensity rainfall long after an earthquake has occurred. For example, destructive debris flows are still known to occur in the areas affected by the 1999 Chi-Chi, 2008 Wenchuan, and 2015 Gorkha earthquakes (Shieh and Tsai, 2009; Zhou et al., 2016; Dahlquist and West, 2019). Post-earthquake debris flows are characterized by their high destructive power, large scale, and the ease with which they form disaster chains (e.g., debris flows block river channels, causing river diversion and flooding of surrounding areas). Therefore, they seriously threaten human safety and endanger roads, bridges, houses, and other facilities (Cui et al., 2013; Chen et al., 2015; Chen K.-T. et al., 2018; Chen et al., 2019a; Chen et al., 2019b; Xiong et al., 2020). Wenjia Gully, in Qingping Township, Mianzhu, Sichuan Province, China, was not a debris flow gully prior to the Wenchuan earthquake. However, in the three rainy seasons immediately after the earthquake, five debris flow events were recorded here. Owing to heavy rainfall on August 13, 2010, the loose material in the channel of Wenjia Gully underwent violent erosion, resulting in a debris flow disaster. The debris flow peak discharge reached $1,530 \mathrm{~m}^{3} / \mathrm{s}$, and approximately $33.1 \times 10^{6} \mathrm{~m}^{3}$ of loose material was transported to the gully mouth. Debris flow material blocked Mianyuan River, forming a dam that was $400 \mathrm{~m}$ long and $820 \mathrm{~m}$ wide. The subsequent river diversion flooded 479 newly constructed houses across and upstream of Wenjia Gully, as a result of which 7 people died, 5 were reported missing, and 39 sustained injuries (Ni et al., 2012; Tang et al., 2012; Yu et al., 2013).

Engineering measures are an effective method to mitigate debris flow disasters. Employing stabilization measures in the formation zone, blocking and drainage measures in the transport zone, and drainage and deposit stopping measures in the deposition zone of debris flow gullies are common approaches used to control debris flow disasters (Ikeya 1989; Cui and Lin, 2013; Chen et al., 2015). Stabilization measures involve stabilizing the slope, reducing erosion of the gully bed, preventing debris flow initiation, and reducing the scale of debris flows by building check dams and bed sills (Ikeya 1989; Piton et al., 2016). For example, to control debris flow disasters in Jiangjia Gully in Yunnan Province, China, a large number of check dams were built across the upstream tributaries of the watershed in 1979. These check dams effectively control erosion, stabilize the slope on both sides, promote the restoration of vegetation, and reduce the frequency of debris flows in the gully (Zeng et al., 2009). Blocking measures refer to the construction of check dams to retain debris flow material, regulate sediment transport, and reduce the destruction of downstream objects by debris flows (Ikeya 1989; Piton and Recking 2016). For example, to control debris flow disasters in the upstream region of Joganji River, Japan, check dams with a total capacity of 5 million $\mathrm{m}^{3}$ were constructed to trap debris flow material (Kanbara and Imamori 2020). Drainage measures refer to the construction of drainage channels, diversion dikes, and other projects to control gully erosion and guide debris flows along the designed path so as to realize the protection of downstream objects (Ikeya 1989; Van Dine 1996). For example, a drainage channel was constructed downstream of the Xiaogangjian debris flow gully in Sichuan Province, China; it crosses the Hanqing Highway and channels part of the debris flow material into a nearby river, effectively preventing debris flows from directly damaging the road (Chen et al., 2015; Chen J. G. et al., 2018). Deposit stopping measures refer to the construction of retention basins or retaining walls to retain debris flow material and protect vulnerable structures and objects. For example, in Jiuzhaigou Valley, Sichuan Province, China, a retaining wall was built on the debris flow fan in Zechawa Gully to retain the debris flow material and protect tourists, highways, and plank roads in the scenic area (Gong et al., 2020).

Compared with debris flow gullies that threaten roads, villages, and towns, debris flows in scenic areas not only threaten human safety and facilities, but also damage landscape resources, cause the deterioration of the ecosystem and ecological environment, and adversely impact the sustainable development of scenic areas, which has attracted extensive attention from scholars around the world (Cui et al., 2003; Faccini et al., 2009; Chen et al., 2016; Wang 2016). For example, debris flows in Jiuzhaigou Valley severely damage scenic landscapes, cause lake siltation, and block scenic roads, which significantly impact normal operations in these areas (Cui et al., 2003; Chen X.-q. et al., 2018). To protect residents, tourists, the natural landscape, and the ecological environment in Jiuzhaigou Valley, engineering measures have been employed to treat 14 debris flow gullies in which serious disasters occurred since 1984. The principles, technical measures, and typical engineering structures used for debris flow control in Jiuzhaigou Valley have been previously discussed (Cui et al., 2003). In the Shuzheng debris flow gully, which poses a threat to Shuzheng Village and the Shuzheng Lakes area, debris flow disasters were effectively controlled by constructing check dams in the formation zone to prevent the formation of conditions conducive to debris flow initiation and to stabilize the slope and gully. In the Xiajijie Lake debris flow gully, which poses a threat to the lake landscape and a nearby highway, check dams were built in the upper reaches of the gully, and a drainage channel with an embankment was constructed in the middle reaches of the gully to divert the debris flow into the forest. Vegetation is used to block debris flow material and realize the organic combination of ecosystem and engineering projects to achieve synergistic disaster reduction (Cui et al., 2007). However, the aforementioned control projects are more than 30 years old. The M7.0 earthquake that struck Jiuzhaigou Valley on August 8, 2017 severely damaged the original control projects in the area, and their capacity to control debris flows was considerably reduced (Huang et al., 2020). Global climate change trends indicate that extreme rainfall events will become more common and that debris flow disasters will become more severe because of the complex terrain conditions in this region (Liu et al., 2020). To manage post-earthquake debris flow disasters in Jiuzhaigou Valley, it is necessary to analyze the characteristics of the disasters and implement appropriate and timely control measures. Based on the characteristics of debris flow disasters, some scholars proposed that the "blocking + deposit stopping" control mode should be adopted to manage these disasters comprehensively (Gong et al., 2020). Other 
scholars point to the fact that the location of debris flow control projects after an earthquake in scenic areas is limited by the functional zoning of the scenic areas; control projects can only be located within the experimental zones of scenic areas, where nature conservation and the sustainable use of resources are effectively combined. The Xiajijie Lake Gully is used as a case study to illustrate that the "blocking," "deposit stopping," and "blocking + deposit stopping" control modes should be adopted to control debris flows in Jiuzhaigou Valley (Zhao et al., 2020). Based on the foregoing analysis, the Jiuzhai Valley National Park Administration Bureau has implemented debris flow control projects in 31 debris flow gullies in the scenic area, some of which were completed in May 2019. However, on June 21, 2019, and July 22, 2019, debris flow disasters occurred in several gullies in the scenic area. The disaster reduction effect of the new control projects was found to be insufficient, and vulnerable structures were not effectively protected. The following shortcomings were noted: 1) there was a lack of planning for a debris flow disaster control system for the entire scenic area; 2) the control scheme for debris flow gullies was not appropriate; and 3) the engineering design parameters of the control scheme were inappropriate.

To overcome the aforementioned challenges, this study aimed to propose an engineering planning method for debris flow control in scenic areas using field investigations and data obtained from control projects in Jiuzhaigou Valley. This planning method consisted of the following steps: 1) The region in which the experimental zone of the scenic area overlapped with the transport and deposition zones of debris flow gullies was taken as the area in which the debris flow control projects could be constructed, so as to realize the systematic planning of debris flow disaster control for the entire scenic area. 2) Based on the objects threatened by debris flows and the topographical characteristics of the debris flow gullies, the "blocking + deposit stopping," "deposit stopping," "blocking," and "drainage + deposit stopping" control modes were adopted for different debris flow gullies in the scenic area to rapidly develop engineering measures for debris flow gullies in the scenic area. 3) The debris flow control projects were planned reasonably, the amount of debris flow material that could be retained by each project structure was quantified using parameter calculation, and the project implementation plan was determined. Based on the engineering planning method for debris flow control in the scenic area, this study discussed the challenges confronting debris flow control engineering in the scenic area, and formulated corresponding engineering schemes for debris flow control in the Xiajijie Lake, Zhuozhui, Pingshitou, Xuan, and WestZhuozhui debris flow gullies.

\section{DEBRIS FLOW DISASTERS AND THEIR MITIGATION MEASURES IN JIUZHAIGOU VALLEY}

\section{Regional Setting of Jiuzhaigou Valley}

Jiuzhaigou Valley is located in Zhangzha Town, Jiuzhaigou County, Sichuan Province, China, approximately $440 \mathrm{~km}$ away from Chengdu, Sichuan Province, China. Jiuzhaigou Valley, which has a basin area of $720 \mathrm{~km}^{2}$, has a high vegetation coverage, stable surface runoff, and adequate groundwater replenishment (https:// en.jiuzhai.com/). As a result of precipitation and groundwater replenishment, a large number of lakes (commonly known as Haizi) are widely distributed in the scenic area, arranged in the form of a string of beads. The largest of these is Long Lake. The terrain of Jiuzhaigou Valley is high in the south and low in the north. The main gully has developed on the northern slope of the Gaerna watershed at the southernmost end of the basin. Water flows from south to north, and most branch gullies merge into the main gully in an east-west direction (Figure 1). Jiuzhaigou Valley is globally renowned for its blue and green lakes, spectacular waterfalls, and narrow conic karst landforms; it was declared a UNESCO World Heritage Site in 1992.

The study area is located between the Qinghai-Tibet Plateau and the Sichuan Basin, in a zone with a high altitude and steep slopes. There are 68 mountains with peaks higher than 4,000 m above sea level ( $\mathrm{m}$ asl) in the area. The highest point is Gaerna in the southernmost region of the watershed, and the lowest point is Yangdong in the northernmost gully of the basin. The maximum elevation difference is $2,768 \mathrm{~m}$, the horizontal distance between the highest and lowest points is approximately $46 \mathrm{~km}$, and the average elevation difference of the entire basin exceeds 1,600 m. These topographic conditions are conducive to the occurrence of debris flows. The study area belongs to the Songpan-Ganzi block, which lies to the east of the Bayanhar block, and the unique geological conditions in the area are the result of the intense activity along the Tazang, Minjiang, and Huya faults. This activity led to the M7.5 Diexi earthquake in 1933, the M6.7 Zhangla earthquake in 1960, the M6.5 Huanglong earthquake in 1973, the Songpan-Pingwu earthquake cluster $\left(\mathrm{M}_{\mathrm{S}}=7.2,6.7\right.$, and 7.2$)$ in 1976, and the M7.0 Jiuzhaigou earthquake in 2017 (Fan X. et al., 2018; Zhao et al., 2018). Frequent seismic activity leads to the fracture and collapse of the rock mass (limestone and slate with a small amount of sandstone) and induces landslides in the study area, which provides an abundant source of loose material for debris flows. In addition, the rainfall in the study area is concentrated from May to September, usually in the form of heavy rain (Gong et al., 2020). Owing to the steep terrain and abundant loose material, debris flow disasters are frequently triggered in the study area when concentrated rainfall events and rainstorms occur.

\section{Debris Flow Mitigation Measures in Jiuzhaigou Valley}

To protect residents, tourists, the natural landscape, and the ecological environment in Jiuzhaigou Valley, engineering control has been carried out on the debris flow gully since 1984 (Cui et al., 2007). Debris flow disasters in the scenic area have recently increased owing to the 2017 Jiuzhaigou M7.0 earthquake; these disasters have damaged infrastructure, destroyed vegetation, and polluted water bodies in the scenic area (Chen X.-q. et al., 2018; Hu et al., 2019; Gong et al., 2020). After the 2017 Jiuzhaigou earthquake, the Jiuzhai Valley National Park Administration Bureau initiated phased treatment of 31 debris flow gullies; the first phase, comprising 15 debris flow gully 


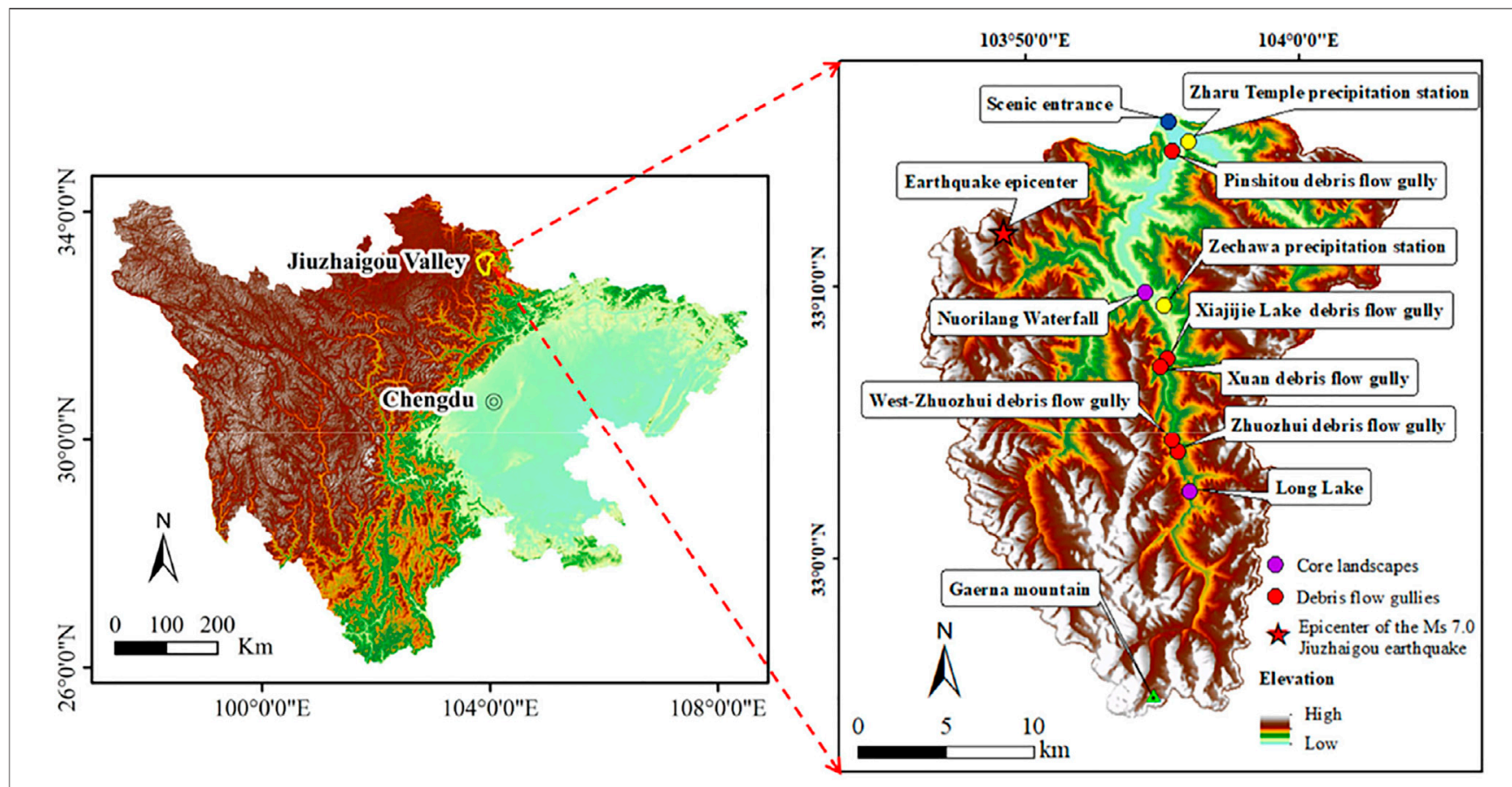

FIGURE 1 | Geomorphological setting of the study area and distribution of debris flow gullies in the area.

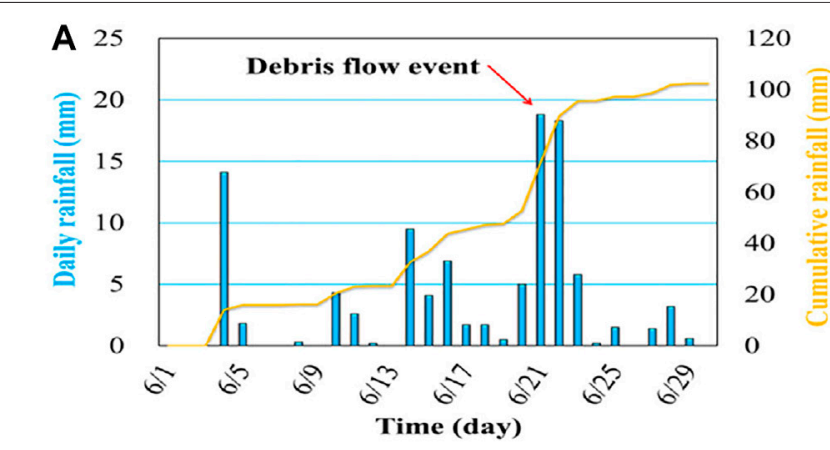

C
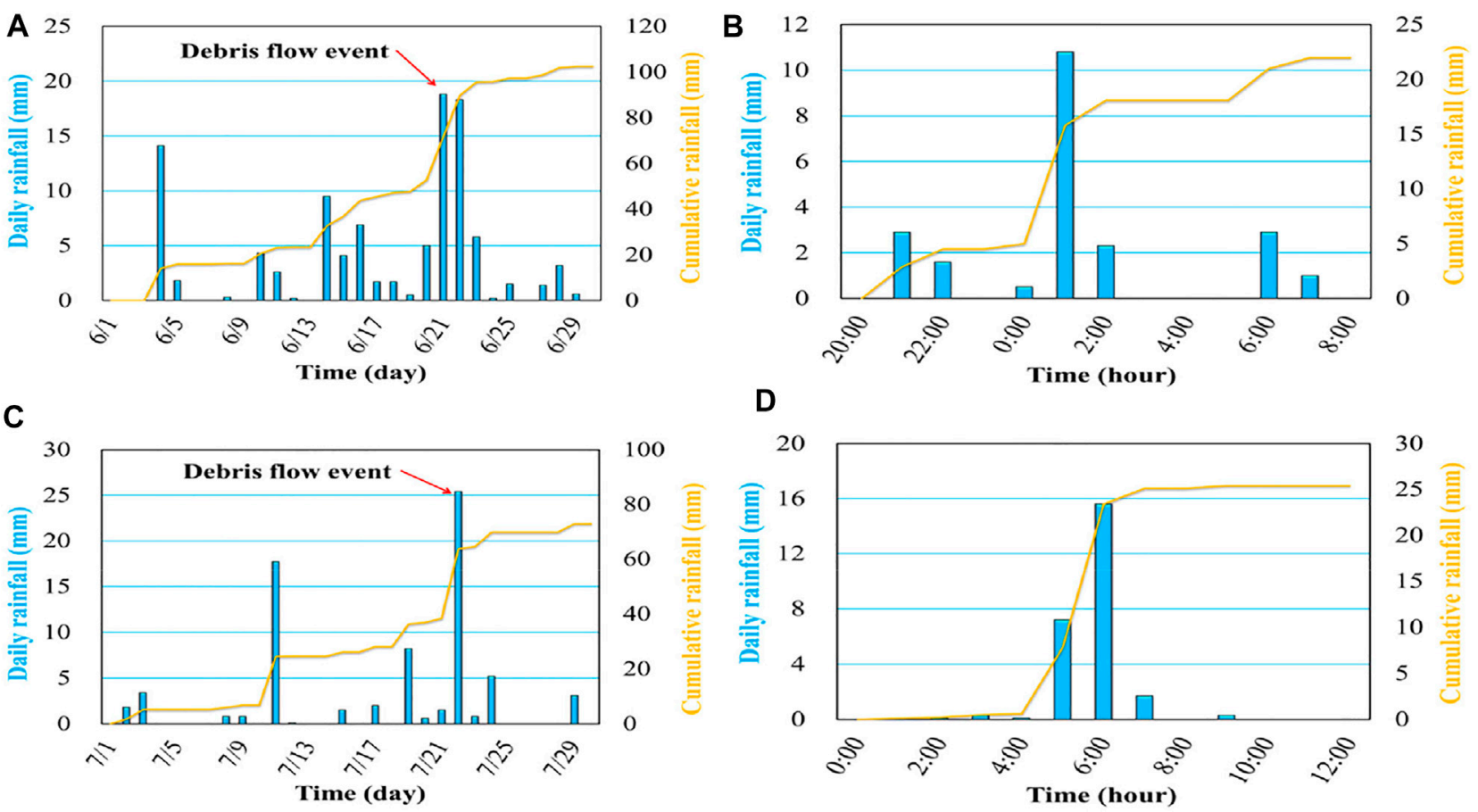

FIGURE 2 | Distribution of daily and hourly rainfall. (A) Daily rainfall in June 2019 recorded by the Zechawa precipitation station; (B) Hourly rainfall from 20:00 (Beijing time) on June 20 to 8:00 (Beijing time) on June 21, 2019 recorded by the Zechawa precipitation station; (C) Daily rainfall in July 2019 recorded by the Zharu Temple precipitation station; (D) Hourly rainfall from 00:00 to 12:00 (Beijing time) on July 22, 2019 recorded by the Zharu Temple precipitation station. 


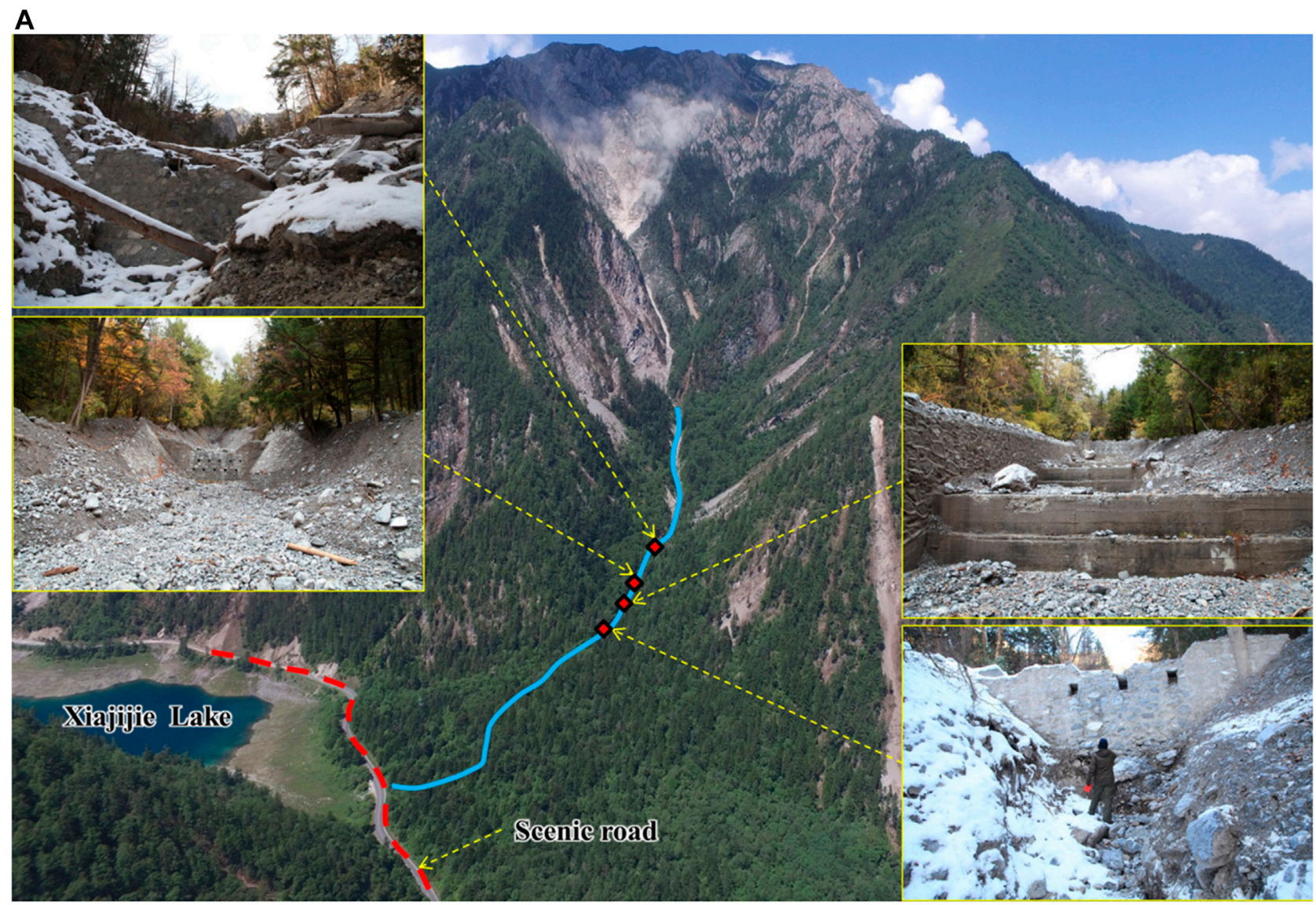

B

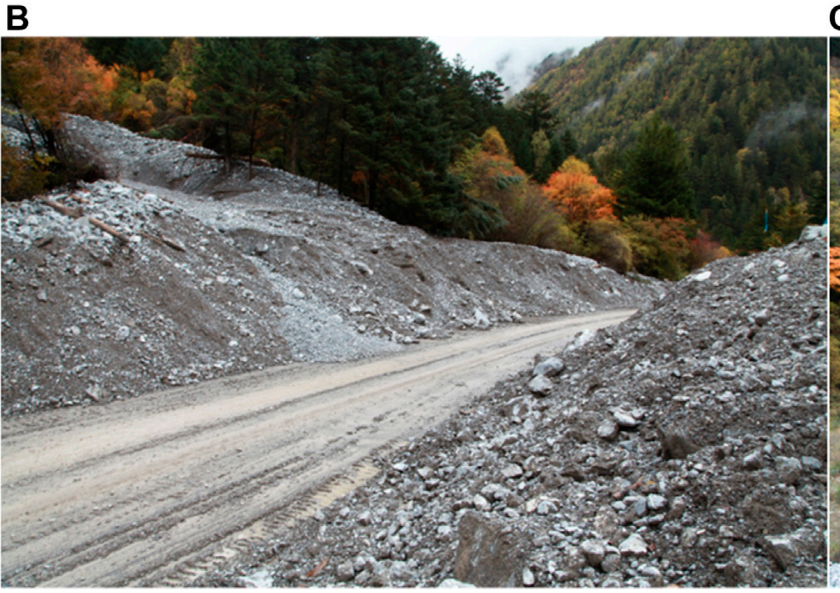

C

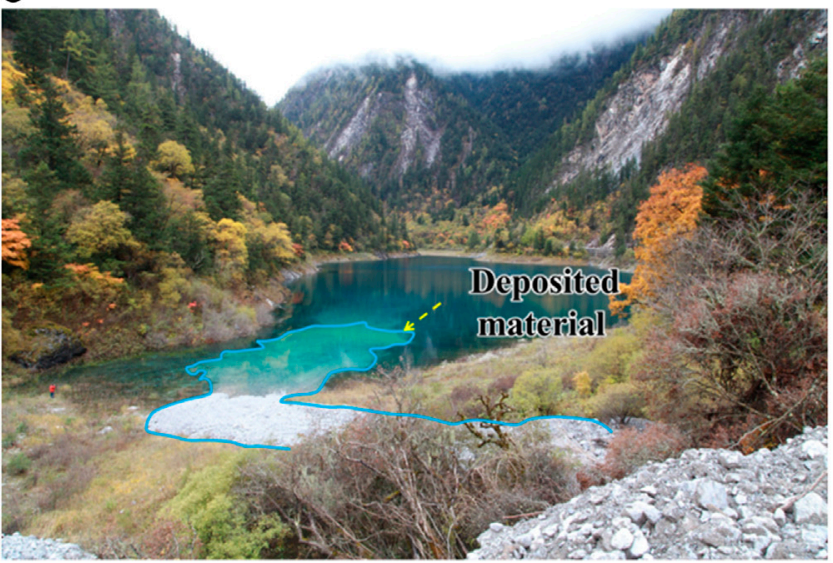

FIGURE 3 | View of Xiajijie Lake Gully. (A) Control engineering layout of Xiajijie Lake Gully (before the debris flow event on June 21, 2019). The blue line in the figure represents the main channel; (B) Debris flow material deposited on the scenic road on September 25, 2017; (C) Debris flow material entering Xiajijie Lake on September $25,2017$.

control projects, was completed in May 2019. From 20:00 (Beijing time) on June 20 to 08:00 (Beijing time) on June 21, 2019, heavy rainfall occurred in Jiuzhaigou Valley. Rainfall data from the Zechawa precipitation station show that the maximum $1 \mathrm{~h}$ rainfall was $10.8 \mathrm{~mm}$, and the cumulative $6 \mathrm{~h}$ rainfall was $18.1 \mathrm{~mm}$ (Figures 2A,B); this rainfall intensity was almost equivalent to that of rainfall with a 2 -years return period. The heavy rainfall induced simultaneous debris flows in Xiajijie Lake,
Xuan, Zhuozhui, Zechawa, Zhongjijie Lake, and West-Zhuozhui in the scenic area; the gully in the West-Zhuozhui area changed from a non-debris flow gully to a debris flow gully during this heavy rainfall event. From 00:00 to 09:00 (Beijing time) on July 22,2019 , heavy rainfall occurred again in the scenic area. Rainfall data from the Zharu Temple precipitation station show that the maximum $1 \mathrm{~h}$ rainfall was $15.6 \mathrm{~mm}$, and the cumulative $6 \mathrm{~h}$ rainfall was $25 \mathrm{~mm}$ (Figures 2C,D); this rainfall intensity was 


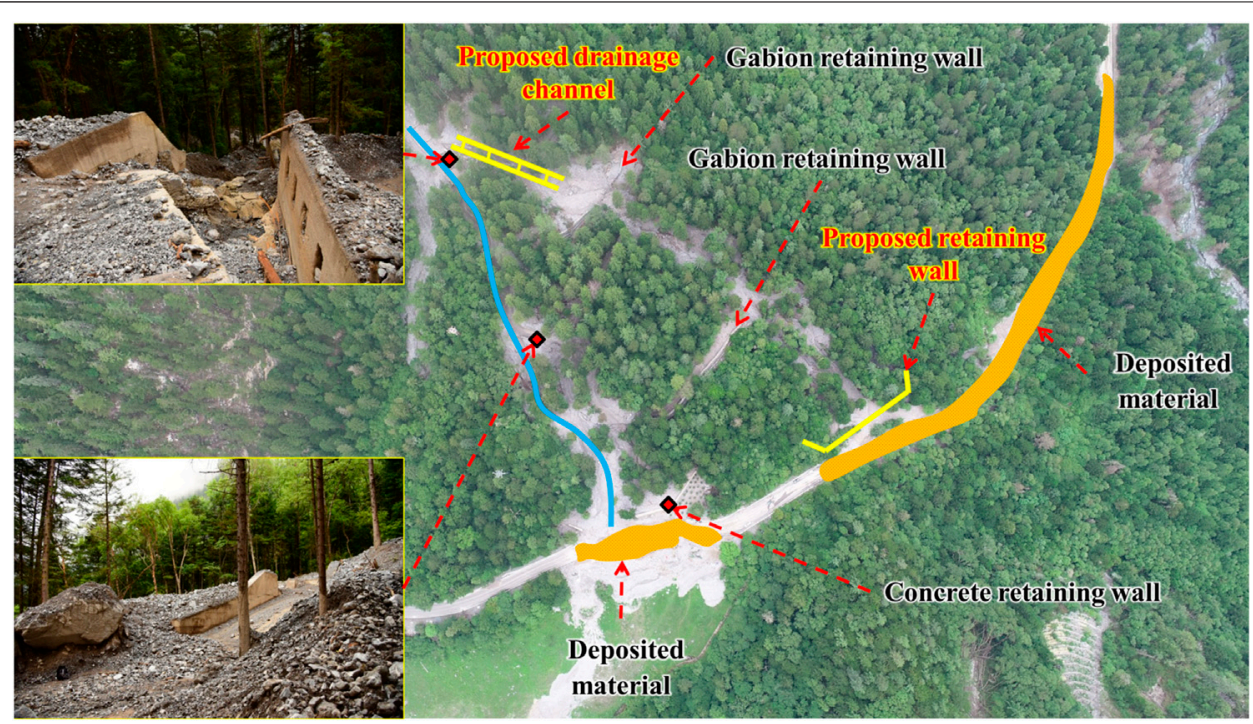

FIGURE 4 | Control engineering layout of Xiajijie Lake Gully (after the debris flow event on June 21, 2019). The blue line in the figure represents the main channel. The proposed drainage channel and retaining wall in the figure are the proposed engineering projects described in Application of the Planning Method for the Xiaijije Lake, Zhuozhui, Pingshitou, Xuan, and West-Zhuozhui Debris Flow Gullies section.

almost equivalent to that of rainfall with a return period of $2-5$ years. The heavy rainfall triggered a debris flow in the scenic area of Pingshitou Gully. Field investigation revealed that the new debris flow control project could not effectively control the debris flow disasters of June 21 and July 22, 2019. The inappropriate control engineering planning scheme and parameter calculation are elucidated using the examples of the Xiajijie Lake, Pingshitou, Zhuozhui, Xuan, and West-Zhuozhui debris flows.

\section{Blocking and Deposit Stopping to Control Debris Flow Disasters in Xiajijie Lake Gully}

Xiajijie Lake Gully is adjacent to Xiajijie Lake. The straight-line distances from this gully to Nuorilang Waterfall and the entrance of Jiuzhaigou Valley are 4.6 and $16.2 \mathrm{~km}$, respectively. The only scenic highway from Nuorilang Waterfall to Long Lake passes through the accumulation fan at the gully mouth (Figure 3A). In general, Xiajijie Lake Gully slopes from west to east; the highest point $(4,120 \mathrm{~m}$ asl $)$ lies on the west side of the basin and the lowest point lies near the mouth of Xiajijie Lake Gully (2,620 $\mathrm{m}$ asl). The watershed area of Xiajijie Lake Gully is $1.87 \mathrm{~km}^{2}$, the length of the main gully is $2.36 \mathrm{~km}$, and the average longitudinal slope gradient of the gully bed is $593 \%$.

To mitigate debris flow disasters in Xiajijie Lake Gully, blocking measures were implemented in the debris flow gully in 1984. Three check dams and a drainage channel with an embankment were constructed in the transport zone of the debris flow gully (Figure 3A). This type of drainage channel can discharge part of the debris flow material to the forest on the left of the gully, and use vegetation to block debris flow, effectively realizing the combined use of ecological and engineering measures to achieve coordinated disaster mitigation. On August 8, 2017, the M7.0 Jiuzhaigou earthquake produced a large quantity of landslide material, which provided an abundant source of loose material for debris flow activity in Xiajijie Lake Gully. On September 25, 2017, a debris flow disaster occurred in Xiajijie Lake Gully. After the debris flow material filled the check dam, part of the debris flow material spilled out into the forest on the left side of the drainage channel, part of the material traveled rapidly along the main gully and flowed out, completely blocking the road in the area (Figure 3B), and part of the material entered Xiajijie Lake (Figure 3C). The debris flow material buried a $150 \mathrm{~m}$ section of the road in the scenic area, and the deposited material was up to $5 \mathrm{~m}$ thick.

In December 2017, the Jiuzhai Valley National Park Administration Bureau carried out treatment of the debris flow gully using the "blocking + deposit stopping" control mode. Three diversion dams were constructed in the transport zone to retain and divert the debris flow material. These dams ensure that a part of the debris flow material enters into the forest on the left and is blocked by retaining walls made of gabions, and another part of the debris flow material moves along the main gully and is blocked by a concrete retaining wall (Figure 4) (Zhao et al., 2020). Owing to heavy rainfall on June 21, 2019, a debris flow disaster occurred in Xiajijie Lake Gully. The diversion dam played an effective role during the debris flow event. A large portion of the debris flow material entered the forest on the left, and only a small portion of the material was transported along the main channel to the gully mouth, where the retaining wall effectively prevented the material from entering the Xiajijie Lake. However, owing to the tremendous destructive power of this post-earthquake debris flow, the debris flow material that was diverted to the left damaged the retaining wall made of gabions. As a result, a large amount of debris flow material was deposited on the scenic road. The length of the road section on which the debris flow material was deposited was $334 \mathrm{~m}$, the width of the deposit was $12-15 \mathrm{~m}$, and the thickness of the 

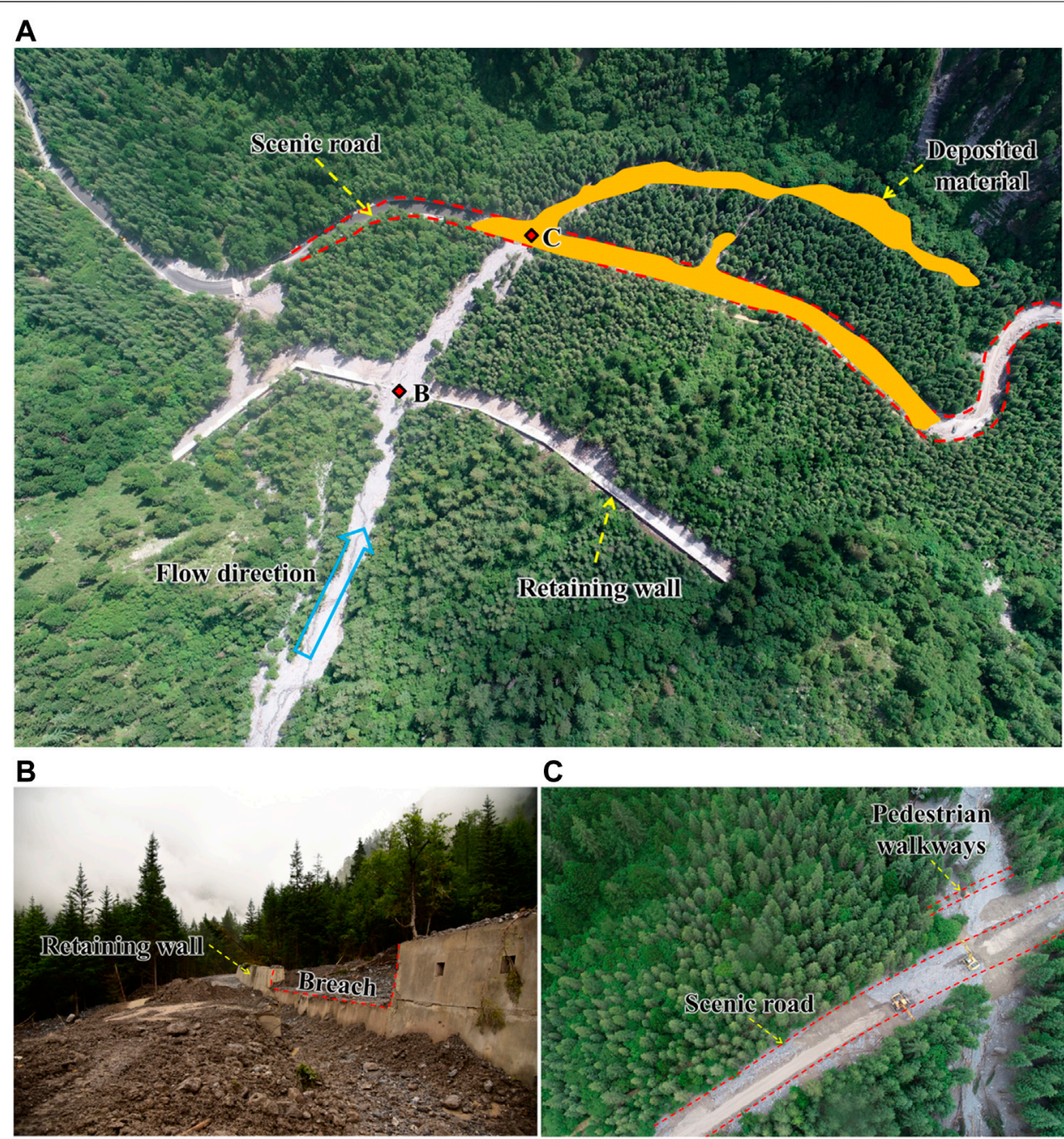

C

FIGURE 5| Mitigation measures in Zhuozhui Gully. (A) Overview of the mitigation structures; (B) The damaged retaining wall, corresponding to point B in (A). (C) The debris flow material deposited on the scenic road, corresponding to point $\mathrm{C}$ in (A).

deposit was 1.5-3.0 $\mathrm{m}$ (Figure 4). By estimating the deposition area and thickness of the debris flow material at the retaining wall, in the forest, and on the road, the total amount of debris flow material was estimated to be $3.3 \times 10^{4} \mathrm{~m}^{3}$.

\section{Deposit Stopping to Control Debris Flow Disasters in Zhuozhui Gully}

Zhuozhui Gully is approximately $25 \mathrm{~km}$ away from the exit of the scenic area. The mouth of the gully is located along the only scenic road from Zechawa village to Long Lake. In a plan view, the watershed of the debris flow gully is leaf-like. The main gully is approximately $3.3 \mathrm{~km}$ in length, and the basin area is about $4.14 \mathrm{~km}^{2}$. The highest point of the gully is $4,492 \mathrm{~m}$ asl, the elevation of the gully mouth is $2,882 \mathrm{~m}$ asl, the relative elevation difference between the highest point and the gully mouth is $1,610 \mathrm{~m}$, and the average longitudinal slope of the gully is about 386\%o. After the 2017 Jiuzhaigou earthquake, a $347 \mathrm{~m}$ long and $3 \mathrm{~m}$ high retaining wall was built in the deposition zone of the debris flow gully to mitigate post-earthquake debris flow disasters in Zhuozhui Gully; the retaining wall had a designed storage capacity of $1.2 \times 10^{4} \mathrm{~m}^{3}$ (Figure 5A). On June 21, 2019, a debris flow disaster was triggered by rainfall in Zhuozhui Gully. The debris flow material was transported to the retaining wall along the gully. Owing to the high impact of the debris flow, the retaining wall was partially damaged along the main channel of the debris flow gully (Figure 5B). Thus, a large amount of debris flow material was transported downstream, resulting in the burial of a $20 \mathrm{~m}$ section of scenic plank road and a $313 \mathrm{~m}$ section of the highway. The thickness of the debris flow material deposited on the scenic road was $2-3 \mathrm{~m}$, and the debris flow continued to move downward into the forest, resulting in the destruction of approximately $3,215 \mathrm{~m}^{2}$ of forest (Figure 5C). By estimating the deposition area and thickness of debris flow material in the retaining wall, road, and forest, the total amount of debris flow material was calculated to be $2.5 \times 10^{4} \mathrm{~m}^{3}$. 


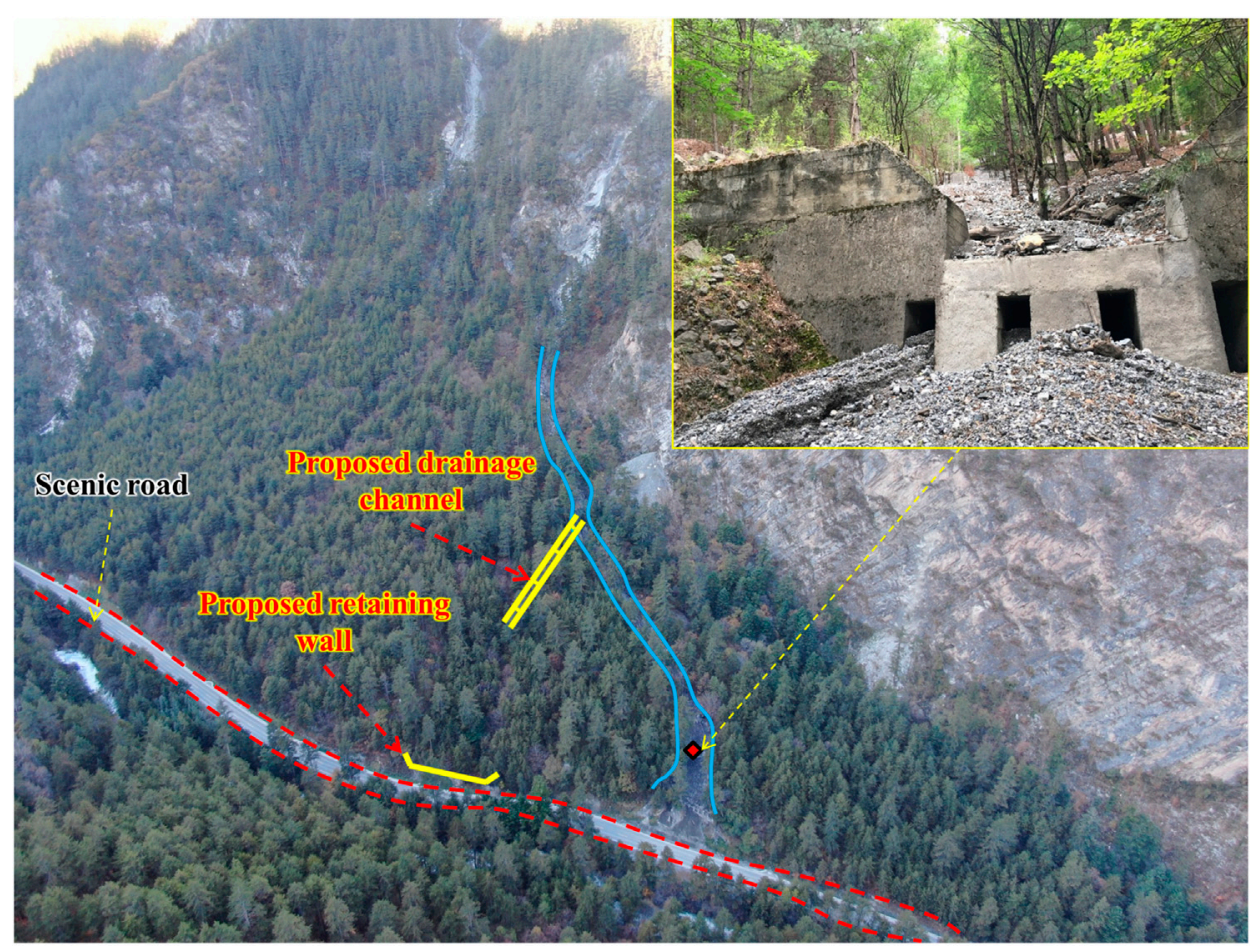

FIGURE 6 | Control engineering layout of Pingshitou Gully (after the debris flow event on July 22, 2019). The blue line in the figure represents the main channel. The drainage channel and the retaining wall in the figure are the proposed engineering projects described in Application of the Planning Method for the Xiaijie Lake, Zhuozhui, Pingshitou, Xuan, and West-Zhuozhui Debris Flow Gullies section.
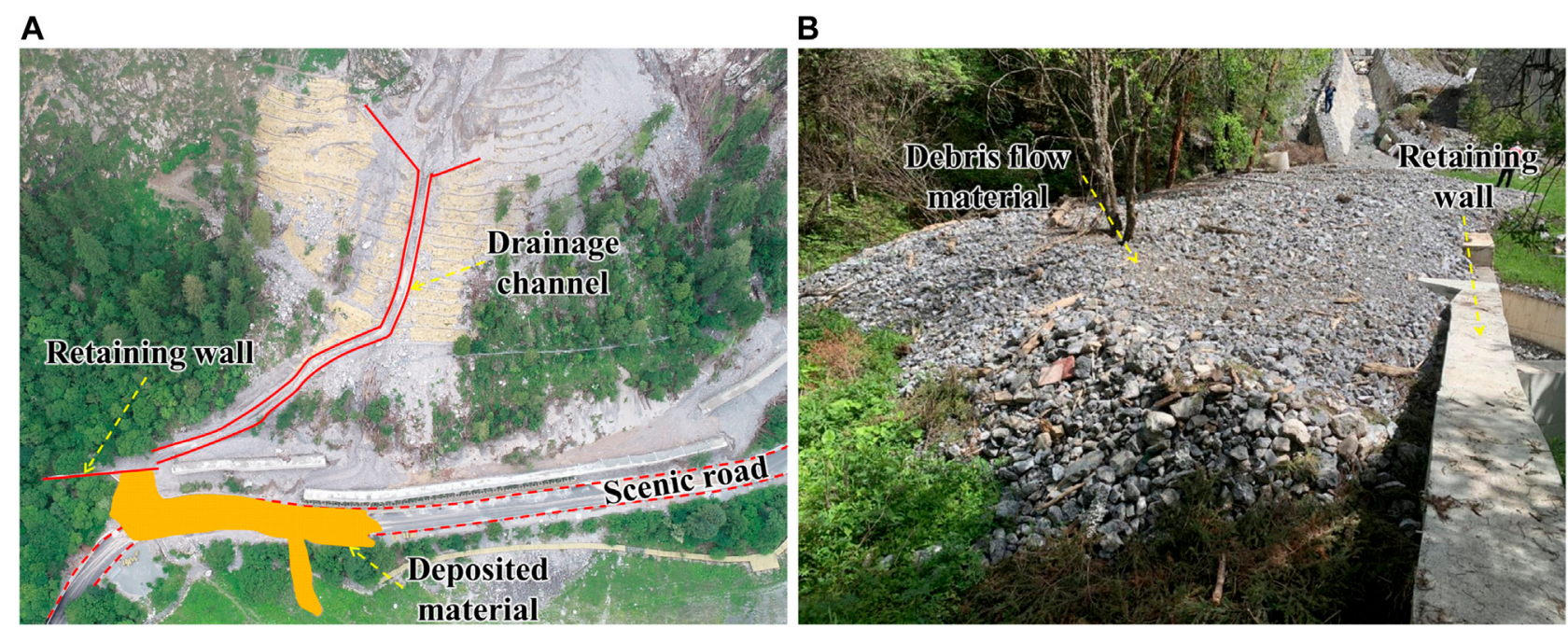

FIGURE 7 | Mitigation measures in Xuan Gully. (A) Overview of the mitigation structures. (B) The debris flow material transported on June $21,2019$.

\section{Blocking to Control Debris Flow Disasters in Pingshitou Gully}

The mouth of Pingshitou Gully is about $2.6 \mathrm{~km}$ away from the entrance of the scenic area. The basin area of the debris flow gully is $0.10 \mathrm{~km}^{2}$, and the length of the main gully is $0.90 \mathrm{~km}$. The lowest point of the gully is located near the scenic road at an altitude of $2,100 \mathrm{~m}$ asl, and the highest point is located at an altitude of $2,970 \mathrm{~m}$ asl. The relative elevation difference of the terrain is $870 \mathrm{~m}$, and the average longitudinal gradient of the gully bed is $775 \%$. To mitigate debris flow disasters, the debris flow gully was treated using the blocking control mode in 1984; five check dams were constructed in the transport zone to retain debris flow material. After the 2017 Jiuzhaigou earthquake, the original check dams were strengthened to mitigate debris flow 


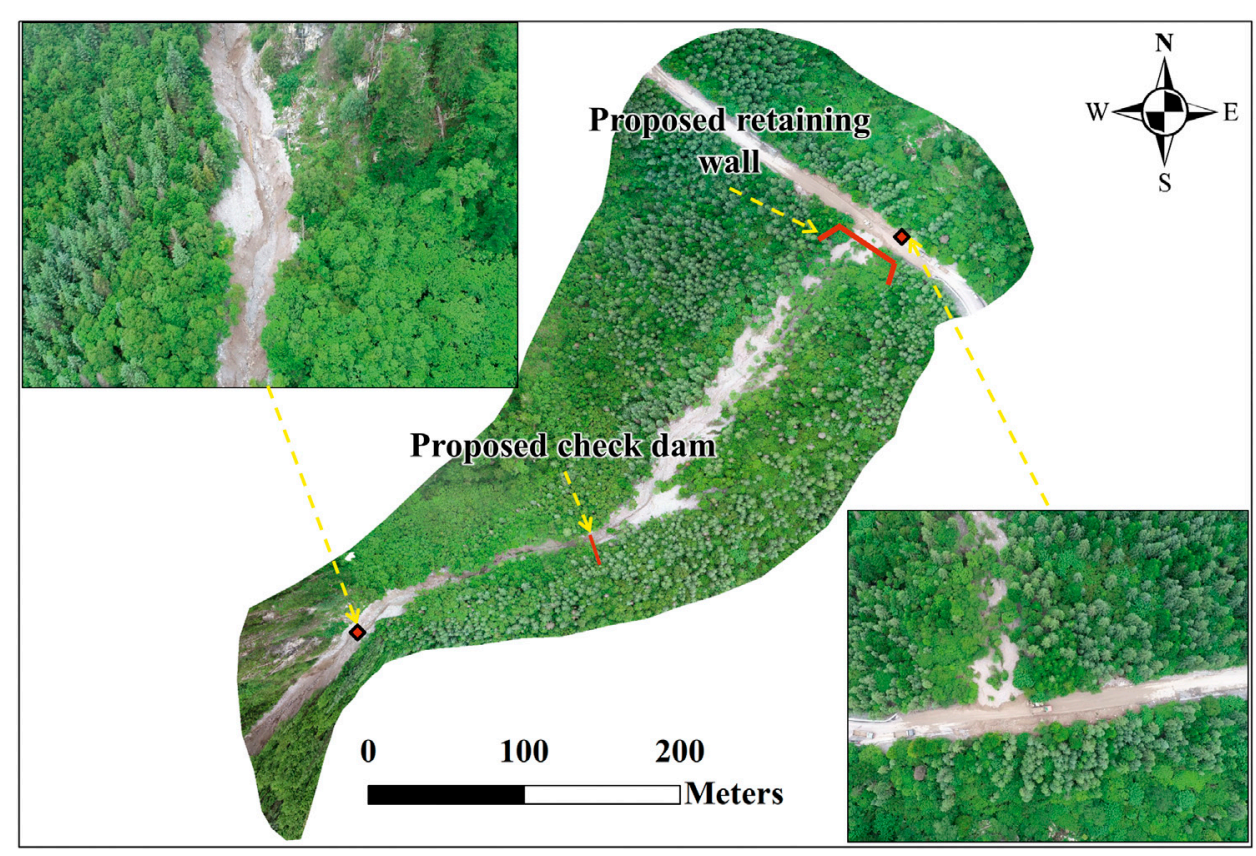

FIGURE 8 | UAV image of the debris flow disaster in West-Zhuozhui Gully on June 21, 2019. The check dam and retaining wall in the figure are the proposed engineering projects described in Application of the Planning Method for the Xiajijie Lake, Zhuozhui, Pingshitou, Xuan, and West-Zhuozhui Debris Flow Gullies section.

disasters. Moreover, the debris flow material behind the check dams was artificially cleared, and the total storage capacity of the check dams after dredging was $0.036 \times 10^{4} \mathrm{~m}^{3}$. A debris flow disaster was triggered by heavy rainfall in Pingshitou Gully on July 22, 2019, and the debris flow material filled the check dams (Figure 6). Approximately $0.2 \times 10^{4} \mathrm{~m}^{3}$ of debris flow material was transported to the scenic road of Pingshitou Gully, which resulted in road blockage.

\section{Drainage and Deposit Stopping to Control Debris Flow Disasters in Xuan Gully}

Xuan Gully is located southwest of Xiajijie Lake. The only scenic highway from Nuorilang Waterfall to Long Lake passes through the accumulation fan at the gully mouth (Figure 7A). The drainage area of the debris flow gully is approximately $0.56 \mathrm{~km}^{2}$, and the length of the main gully is $1.05 \mathrm{~km}$. The highest point of the gully is located in the northwest corner (elevation of 3,805 $\mathrm{m}$ asl), and the lowest point is located near the scenic road (elevation of 2,625 $\mathrm{m}$ asl). The relative elevation difference of the terrain is $1,180 \mathrm{~m}$, and the average longitudinal slope is 795\%o. To mitigate debris flow disasters, drainage measures were implemented in 1984. A drainage channel was constructed in the transport zone of the debris flow gully to discharge debris flow material to the right side of the mouth of the debris flow gully, to manage debris flow disasters in Xuan Gully after the 2017 Jiuzhaigou earthquake, the original drainage channel was repaired and a retention basin with a storage capacity of $0.17 \times 10^{4} \mathrm{~m}^{3}$ was built in the concave area to the right of the gully mouth. On June 21, 2019, a debris flow disaster occurred in Xuan Gully, and debris flow material entered the retention basin through the drainage channel. After the retention basin was full, about $0.11 \times 10^{4} \mathrm{~m}^{3}$ of debris flow material reached the scenic road, blocking it and causing a traffic jam (Figures 7A,B). The debris flow material buried a $108 \mathrm{~m}$ section of the road; the width of the deposit was 9-12 $\mathrm{m}$ and the average thickness of the deposit was $1 \mathrm{~m}$.

\section{Debris Flow Disaster in West-Zhuozhui Gully Without Engineering Measures}

West-Zhuozhui Gully is located on the left side of the road from Long Lake to Nuorilang Waterfall. The straight-line distance from this location to the mouth of Zhuozhui Gully is $600 \mathrm{~m}$. The basin area of the debris flow gully is $1.33 \mathrm{~km}^{2}$, and the length of the main gully is $1.77 \mathrm{~km}$. The lowest point of the gully is located near the scenic road at an altitude of $2,831 \mathrm{~m}$ asl, and the highest point is located at an altitude of 3,993 $\mathrm{m}$ asl. The relative elevation difference of the terrain is $1,162 \mathrm{~m}$, and the average longitudinal gradient of the gully bed is 517\%o. Prior to the 2017 Jiuzhaigou earthquake, no debris flow disaster was recorded in West-Zhuozhui Gully. On June 21, 2019, heavy rainfall triggered severe channel erosion in West-Zhuozhui Gully (Figure 8), and approximately $0.903 \times 10^{4} \mathrm{~m}^{3}$ of loose material was transported to the accumulation fan at the gully mouth and the highway in the scenic area. The debris flow material was deposited on a $120 \mathrm{~m}$ section of the scenic highway; the width of the deposit was $12-16 \mathrm{~m}$, the thickness of the deposit was $1.5-2.5 \mathrm{~m}$, and the volume of the material deposited was $0.336 \times 10^{4} \mathrm{~m}^{3}$ (Figure 8).

\section{Mitigation Effectiveness of Debris Flow Control Projects Completed in May 2019}

As a consequence of the 2017 Jiuzhaigou earthquake, the scale of debris flows in Xiajijie Lake Gully, Zhuozhui Gully, Pingshitou 
TABLE 1 | Mitigation effectiveness of the debris flow control projects completed in May 2019.

\begin{tabular}{|c|c|c|c|c|c|c|c|c|}
\hline \multirow[t]{2}{*}{$\begin{array}{l}\text { Debris flow } \\
\text { gullies }\end{array}$} & \multirow[t]{2}{*}{$\begin{array}{l}\text { Design } \\
\text { standards }\end{array}$} & \multirow[t]{2}{*}{ Control measures } & \multirow[t]{2}{*}{$\begin{array}{l}\text { Engineering } \\
\text { structures }\end{array}$} & \multirow[t]{2}{*}{$\begin{array}{l}\text { Designed capacity } \\
\qquad\left(\mathrm{m}^{3}\right)\end{array}$} & \multirow{2}{*}{$\begin{array}{c}\text { Amount of } \\
\text { transported } \\
\text { debris } \\
\text { flow material } \\
\text { in } 2019 \\
\left(\mathrm{~m}^{3}\right)\end{array}$} & \multicolumn{3}{|c|}{$\begin{array}{l}\text { Whether the following were } \\
\text { endangered in 2019? }\end{array}$} \\
\hline & & & & & & Tourists & $\begin{array}{c}\text { Scenic } \\
\text { road, } \\
\text { walkways }\end{array}$ & Landscapes \\
\hline $\begin{array}{l}\text { Xiajijie Lake } \\
\text { Gully }\end{array}$ & $\begin{array}{l}\text { 50-year return } \\
\text { period (50-year } \\
\text { return period) }\end{array}$ & $\begin{array}{l}\text { Blocking and deposit } \\
\text { stopping measures } \\
\text { (Drainage and } \\
\text { deposit stopping } \\
\text { measures) }\end{array}$ & $\begin{array}{l}\text { Check dams, drainage } \\
\text { channel, retaining walls } \\
\text { (Drainage channel, } \\
\text { retaining wall) }\end{array}$ & $3.0 \times 10^{4}\left(3.01 \times 10^{4}\right)$ & $3.3 \times 10^{4}$ & No & Yes & No \\
\hline $\begin{array}{l}\text { Zhuozhui } \\
\text { Gully }\end{array}$ & $\begin{array}{l}\text { 20-year return } \\
\text { period (50-year } \\
\text { return period) }\end{array}$ & $\begin{array}{l}\text { Deposit stopping } \\
\text { measure (Deposit } \\
\text { stopping measure) }\end{array}$ & $\begin{array}{l}\text { Retaining wall } \\
\text { (Retaining wall) }\end{array}$ & $1.2 \times 10^{4}\left(2.1 \times 10^{4}\right)$ & $2.5 \times 10^{4}$ & No & Yes & - \\
\hline $\begin{array}{l}\text { Pingshitou } \\
\text { Gully }\end{array}$ & $\begin{array}{l}\text { 20-year return } \\
\text { period (50-year } \\
\text { return period) }\end{array}$ & $\begin{array}{l}\text { Blocking measure } \\
\text { (Drainage and } \\
\text { deposit stopping } \\
\text { measures) }\end{array}$ & $\begin{array}{l}\text { Check dams (Drainage } \\
\text { channel, retaining wall) }\end{array}$ & $0.036 \times 10^{4}\left(0.32 \times 10^{4}\right)$ & $0.236 \times 10^{4}$ & No & Yes & - \\
\hline Xuan Gully & $\begin{array}{l}\text { 20-year return } \\
\text { period (50-year } \\
\text { return period) }\end{array}$ & $\begin{array}{l}\text { Drainage and } \\
\text { deposit stopping } \\
\text { measures (Drainage } \\
\text { and deposit stopping } \\
\text { measures) }\end{array}$ & $\begin{array}{l}\text { Drainage channel, } \\
\text { retaining wall (Drainage } \\
\text { channel, retaining wall) }\end{array}$ & $0.17 \times 10^{4}\left(0.72 \times 10^{4}\right)$ & $0.28 \times 10^{4}$ & No & Yes & No \\
\hline $\begin{array}{l}\text { West- } \\
\text { Zhuozhui } \\
\text { Gully }\end{array}$ & $\begin{array}{l}\text { (50-year return } \\
\text { period) }\end{array}$ & $\begin{array}{l}\text { None (Blocking and } \\
\text { deposit stopping } \\
\text { measures) }\end{array}$ & $\begin{array}{l}\text { None (Check dam, } \\
\text { retaining wall) }\end{array}$ & $\left(1.046 \times 10^{4}\right)$ & $0.903 \times 10^{4}$ & No & Yes & - \\
\hline
\end{tabular}

Note: The data and content in parentheses show the results obtained using the engineering planning method for debris flow disasters in scenic areas proposed in Engineering Planning Method for Debris Flow Disasters in Scenic Areas and Application of the Planning Method for the Xiaijijie Lake, Zhuozhui, Pingshitou, Xuan, and West-Zhuozhui Debris Flow Gullies sections.

Gully, and Xuan Gully increased significantly. The gully in West-Zhuozhui changed from a non-debris flow gully before the earthquake to a debris flow gully. Debris flow disasters exhibit a tendency to occur in clusters. Previous studies have shown that debris flow disasters will continue to occur for at least 5-10 years after the earthquake (Chen X.-q. et al., 2018). Therefore, it is necessary to analyze the disaster characteristics of debris flows and implement appropriate and timely control engineering measures. After the 2017 Jiuzhaigou earthquake, the "blocking + deposit stopping," "deposit stopping," "blocking," and "drainage + deposit stopping" control modes were adopted to manage the debris flow disasters in Xiajijie Lake Gully, Zhuozhui Gully, Pingshitou Gully, and Xuan Gully, respectively. The construction of the new projects was completed in May 2019. However, during the debris flow events on June 21, 2019 and July 22, 2019, the new control projects did not effectively protect the vulnerable objects, and the control project schemes and parameter calculations were found to be inappropriate. The specific considerations were as follows: 1) The main gully mouth of Xiajijie Lake exhibits conditions that are not conducive to deposit stopping; thus, it is not appropriate to construct a retaining wall at the main gully mouth. The retention conditions of the transport zone in Pingshitou Gully are poor; thus, blocking is not an appropriate control mode to manage debris flow disasters. 2) The total designed storage capacity of the debris flow control engineering project in Zhuozhui Gully, Pingshitou Gully, and Xuan Gully is far lower than the amount of transported debris flow material. Therefore, to effectively overcome these challenges, this study combined field investigation and data collection, and proposed a method of debris flow control engineering planning in scenic areas taking into account the characteristics of different debris flow gullies and the engineering feasibility. The application of this method is illustrated in Engineering Planning Method for Debris Flow Disasters in Scenic Areas section, using the example of Jiuzhaigou Valley, and the mitigation effectiveness of debris flow control projects completed in May 2019 is analyzed in Table 1.

\section{ENGINEERING PLANNING METHOD FOR DEBRIS FLOW DISASTERS IN SCENIC AREAS}

In China, owing to restrictions related to the functional zoning of nature reserves, debris flow control projects can only be constructed in experimental zones. The formation zones of debris flow gullies in scenic areas are usually located in the core and buffer zones of these areas. Typically, only the transport and deposition zones of debris flow gullies overlap with the experimental zones of scenic areas, which make it impossible to implement stabilization measures in the formation zones of debris flow gullies. Therefore, all types of control projects can only be implemented in the transport zones and deposition zones of debris flow gullies to realize the management of debris flow disasters in scenic areas. Based on field investigations and data collected from debris flow control 


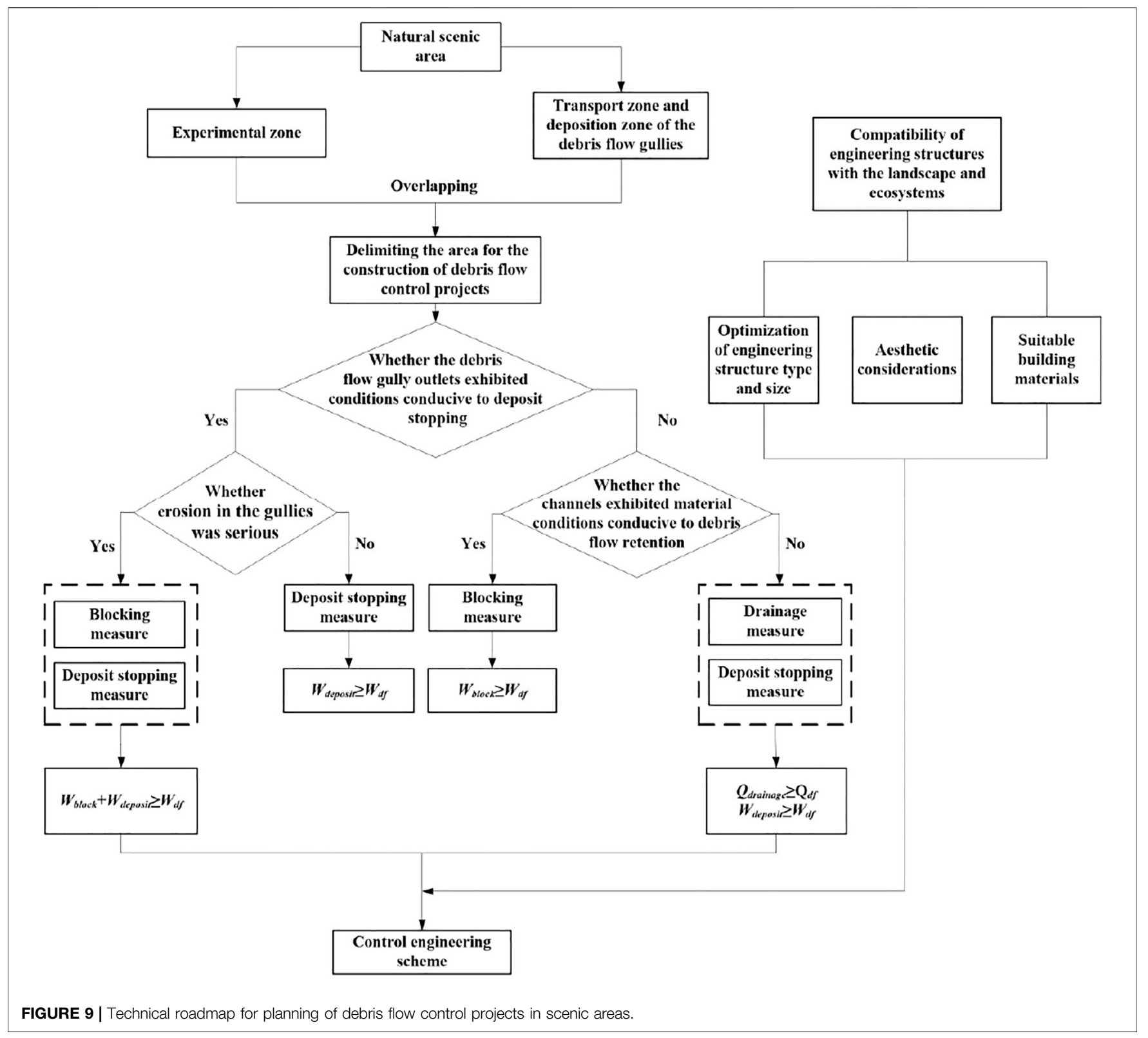

projects in scenic areas, an engineering planning method for debris flow control projects in scenic areas is proposed. The specific steps are described in Figure 9:

\section{Delimiting the Area for the Construction of Debris Flow Control Projects}

Based on data related to protected objects in scenic areas, the natural environment and natural resources, social economy, and land and water utilization, the National Standard of the People's Republic of China (Cui et al., 2018) spatially divides scenic areas into core, buffer, and experimental zones (Figure 10). Based on field investigations and topographic surveys, debris flow gullies are divided into formation zones, transport zones, and deposition zones. Debris flow control projects can only be constructed in areas in which the experimental zones of the natural scenic areas overlap with the transport and deposition zones of debris flow gullies.

\section{Obtaining Topographic Conditions and Constructing Debris Flow Control Projects}

Using field investigations and topographic surveys, this study determined whether the debris flow gully mouths exhibited conditions conducive to deposit stopping, whether the channels in the transport zones exhibited material conditions conducive to debris flow retention, and whether erosion in the gullies was serious. Our study can provide the basis for the formulation of control engineering schemes.

For debris flow gullies in which conditions at the gully mouths are conducive to deposit stopping, the following 


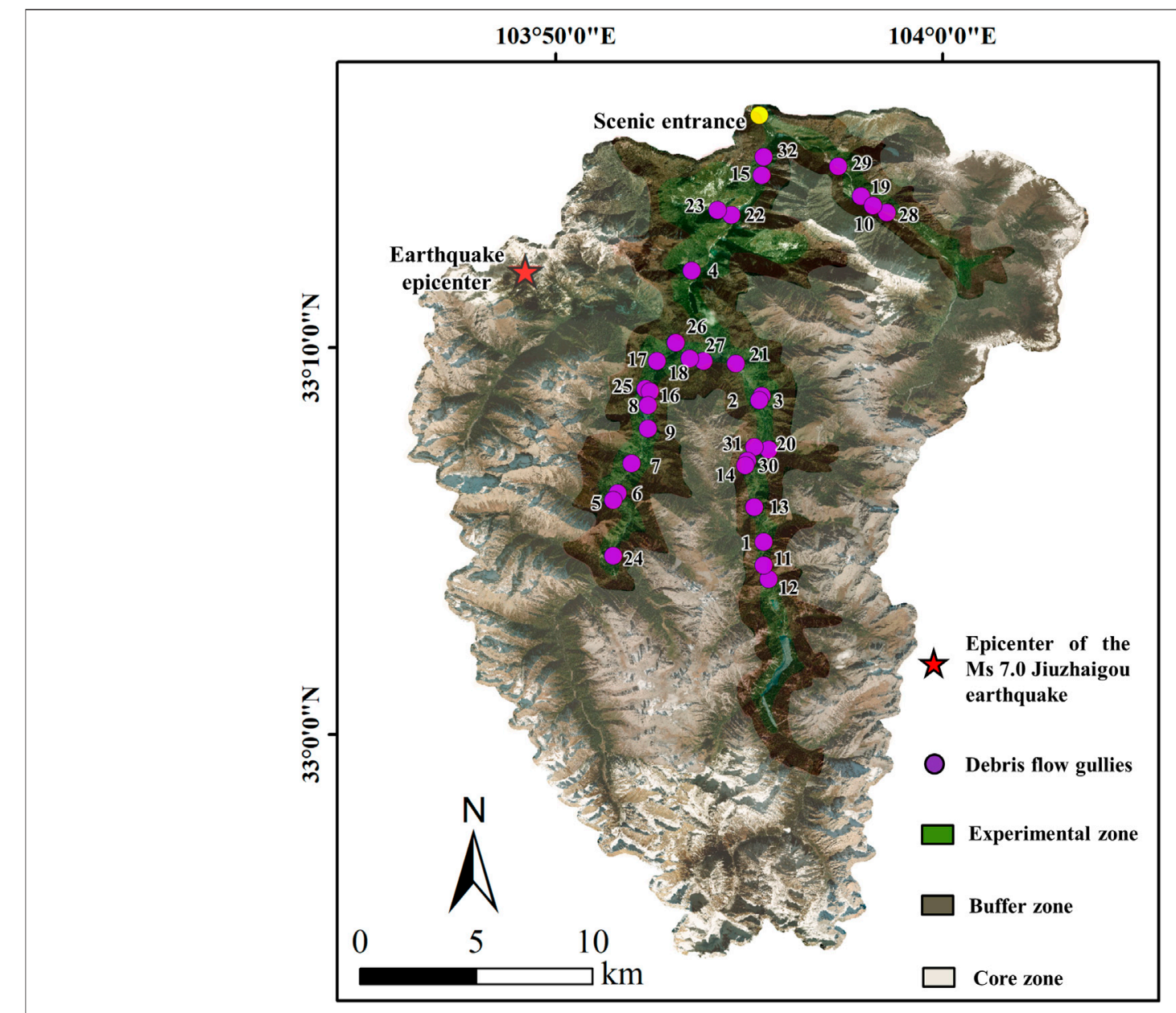

FIGURE 10 | Functional zoning map of Jiuzhaigou Valley.

considerations should be applied. When gully erosion is severe, blocking projects should be constructed in the transport zone and deposit stopping projects should be constructed in the deposition zone of the debris flow gully within the construction area of debris flow control projects. The blocking projects and deposit stopping projects should jointly meet the following requirement: the amount of debris flow material retained by the blocking projects $\left(W_{\text {block }}\right)+$ the amount of debris flow material retained by the deposit stopping projects $\left(W_{\text {deposit }}\right)>$ the total volume of debris flow material under design standards $\left(W_{d f}\right)$. When gully erosion is not severe, it is only necessary to construct deposit stopping projects in the deposition zone within the construction area of debris flow control projects. The deposit stopping projects should meet the following requirement: the amount of debris flow material retained by the deposit stopping projects ( $\left.W_{\text {deposit }}\right)$ $>$ the total volume of debris flow material projected to rush out under design standards $\left(W_{d f}\right)$.

For debris flow gullies in which conditions at the gully mouths are not conducive to deposit stopping, the following considerations should be taken into account. When the channel in the transport zone exhibits material conditions conducive to debris flow retention, it is only necessary to construct blocking projects in the transport zone in the construction area of debris flow control projects. The blocking projects should meet the following requirement: the amount of debris flow material retained by the blocking project $\left(W_{\text {block }}\right)>$ the total volume of debris flow material projected to rush out under design standards $\left(W_{d f}\right)$. When the channel in the transport zone does not exhibit material conditions conducive to debris flow retention, drainage projects should be constructed in the transport zone in the construction area of debris flow control projects to discharge debris flow material into the recesses on both the sides of the gully; these should be accompanied by deposit stopping projects. The drainage projects should meet the following requirement: the peak discharge of the debris flow material discharged by the drainage projects $\left(Q_{\text {drainage }}\right)>$ the peak discharge of debris flow material projected to rush out under design standards $\left(Q_{d f}\right)$. The amount of debris flow material retained by the deposit stopping projects $\left(W_{\text {deposit }}\right)>$ the total volume of debris flow material projected to rush out under design standards $\left(W_{d f}\right)$. The method of calculation of all the aforementioned parameters is described in Parameter Calculation section. 


\section{Parameter Calculation Debris Flow Peak Discharge Under Different Return Periods $\left(Q_{d f}\right)$}

The design standard of a control project determines the ability of the project to withstand debris flow disasters. Based on the risk level of the vulnerable objects or the disaster situation of the affected objects, the design standards of debris flow control projects in mountainous areas in China can be divided into 100, 50, and 20-year return periods (Chen et al., 2015; Liu et al., 2015; Gong et al., 2020). Considering the importance of scenic areas, a 50 -year return period should be adopted as the design standard for debris flows. The rain-flood method is a widely used method to calculate the peak discharge of debris flows. The peak discharge $Q_{d f}$ of debris flows under different design standards can be obtained through the following steps (Zhou et al., 1991; Liu et al., 2014; Gong et al., 2020).

Step one: based on topographic data, the basin area, $A\left(\mathrm{~km}^{2}\right)$, length of the main gully, $L(\mathrm{~km})$, and average longitudinal gradient of the gully bed, $J$, are obtained. Then, the basin characteristic parameter of the gully, $\theta$, is calculated using Eq. 1 and the confluence parameter, $m$, is calculated using Eq. 2 .

$$
\begin{gathered}
\theta=\frac{L}{J^{1 / 3} A^{1 / 4}} \\
m=0.221 \theta^{0.204}
\end{gathered}
$$

Step two: the characteristic rainstorm values $[1 / 6 \mathrm{~h}$ average rainfall, $H_{1 / 6}(\mathrm{~mm}), 1 \mathrm{~h}$ average rainfall, $H_{1}(\mathrm{~mm})$, and $6 \mathrm{~h}$ average rainfall, $H_{6}(\mathrm{~mm})$ ] of debris flow gullies are obtained from the rainstorm and flood calculation manual of medium-small basins in Sichuan Province. The modulus coefficients, $K_{1 / 6}, K_{1}$, and $K_{6}$, corresponding to $H_{1 / 6}, H_{1}$, and $H_{6}$, are obtained from the Pearson III frequency table. Eq. 3 is used to calculate the rainstorm intensity, $S(\mathrm{~mm})$, under the design standard, and Eq. 4 is used to calculate the rainstorm attenuation index, $n$.

$$
n=\left\{\begin{array}{c}
S=H_{1} K_{1} \\
1+1.285\left(1 g \frac{H_{1 / 6} K_{1 / 6}}{H_{1} K_{1}}\right), 1 / 6 h<t<1 h \\
1+1.285\left(1 g \frac{H_{1} K_{1}}{H_{6} K_{6}}\right), 1 h<t<6 h
\end{array},\right.
$$

Step three: the confluence time, $t(\mathrm{~h})$, and flood peak runoff coefficient, $\varphi$, are calculated using Eqs 5-8.

$$
\begin{aligned}
t & =t_{0} \varphi^{-\frac{1}{4-n}} \\
\varphi & =1-1.1 \frac{\mu}{S} t_{0}^{n} \\
t_{0} & =\left[\frac{0.383}{m S^{1 / 4} / \theta}\right]^{\frac{4}{4-n}} \\
\mu & =K_{P} \eta A^{-0.19}
\end{aligned}
$$

where $t_{0}$ is the basin confluence time when $\varphi=1, \mu$ is the basin runoff yield parameter $(\mathrm{mm} / \mathrm{h})$, and $\eta$ is the comprehensive coefficient of runoff yield parameters. Based on the area in which the debris flow gully is located, the values of $\eta$ are 6 (Qingyi River-Lutou Mountain rainstorm area), 4.8 (basin hilly area), and 3.6 (basin margin mountainous area and southwest mountainous area), respectively. $K_{p}$ is the modulus ratio coefficient when the variation coefficient is 0.23 , which is obtained from the Pearson III frequency table.

Step four: the peak discharge of the watershed $Q_{f}\left(\mathrm{~m}^{3} / \mathrm{s}\right)$ is calculated using Eq. 9. Then, the peak discharge of the debris flow $Q_{d f}\left(\mathrm{~m}^{3} / \mathrm{s}\right)$ under the design standard is calculated according to Eq. 10.

$$
\begin{aligned}
Q_{f} & =0.278 \varphi \frac{S}{t^{n}} A \\
Q_{d f} & =D_{d f}\left(1+\psi_{d f}\right) Q_{f} \\
\psi_{d f} & =\left(\gamma_{d f}-\gamma_{w}\right) /\left(\gamma_{s}-\gamma_{d f}\right)
\end{aligned}
$$

where $D_{d f}$ is the blockage coefficient. The value of $D_{d f}$ varies with the degree of blockage, namely, very serious blockage $\left(D_{d f}=3.0-2.6\right)$, serious blockage $\left(D_{d f}=2.5-2.0\right)$, normal blockage $\left(D_{d f}=1.9-1.5\right)$, and minor blockage $\left(D_{d f}=1.4-1.1\right) . \psi_{d f}$ is the amplification coefficient of the debris flow peak discharge. $\gamma_{d f}$ is the density of the debris flow $\left(\mathrm{t} / \mathrm{m}^{3}\right)$, which is obtained via field investigations (Ministry of Land and Resources of the People's Republic of China, 2006). $\gamma_{w}$ is the density of water $\left(\mathrm{t} / \mathrm{m}^{3}\right)$, usually taken as $1.00 \mathrm{t} / \mathrm{m}^{3} \cdot \gamma_{s}$ is the density of the solid material $\left(\mathrm{t} / \mathrm{m}^{3}\right)$, usually taken as $2.65 \mathrm{t} / \mathrm{m}^{3}$.

\section{Debris Flow Peak Discharge by Drainage Channel $\left(Q_{\text {drainage }}\right)$}

Based on the morphology of the cross-section of the drainage channel, the debris flow peak discharge by the drainage channel, $Q_{\text {drainage }}\left(\mathrm{m}^{3} / \mathrm{s}\right)$, can be obtained using Eq. 12:

$$
Q_{\text {drainage }}=A_{\text {drainage }} V_{d f}
$$

where $A_{\text {drainage }}$ is the area of the cross-section of the drainage channel $\left(\mathrm{m}^{2}\right)$, and $V_{d f}$ is the average velocity of the debris flow $(\mathrm{m} /$ s), which can be calculated using Manning's formula (Liu et al., 2015; Gong et al., 2020):

$$
V_{d f}=\frac{1}{n_{\text {drainage }}} R_{d f}^{2 / 3} I_{\text {drainage }}^{1 / 2}
$$

where $n_{\text {drainage }}$ is the roughness coefficient of the drainage channel, which depends on the material properties of the drainage channel, and can be obtained from (China Association of Geological Hazard Prevention 2018). $R_{d f}$ is the hydraulic radius of the debris flow $(\mathrm{m}) . I_{\text {drainage }}$ is the longitudinal slope gradient of the drainage channel bed $(\mathrm{m} / \mathrm{m})$.

\section{Total Volume of Debris Flow Material $\left(W_{d f}\right)$}

The total volume of debris flow material under the design standard, $W_{d f}$ is calculated using Equation (14) (Zhou et al., 1991; Gong et al., 2020):

$$
W_{d f}=0.264 Q_{d f} T_{d f}
$$

where $Q_{d f}$ is the peak discharge of the debris flow under the design standard, which can be calculated using Eq. 10. $T_{d f}$ is the duration 
of the debris flow event, which can be determined by interviewing witnesses and monitoring.

\section{Volume of Debris Flow Material Trapped by Blocking} Projects $\left(W_{\text {block }}\right)$

Since check dams are generally used in blocking projects, $W_{\text {block }}$ can be estimated using the following commonly used equation (Jiang 2018).

$$
W_{\text {block }}=\frac{H_{b}^{2}}{I}\left(\frac{H_{b}}{2 \tan \alpha}+b\right)
$$

where $H_{b}$ is the effective height of the check dam (m), $I$ is the longitudinal slope of the gully at the project site, $\alpha$ is the gradient of the bank slopes of check dams (degrees), and $b$ is the average bottom width of the gully bed in the silting section of the check dam (m). $I, \alpha$, and $b$ are determined based on topographic data of the debris flow gully and field investigations.

\section{Volume of Debris Flow Material Trapped by Deposit Stopping Projects $\left(W_{\text {deposit }}\right)$}

Because deposit stopping projects generally adopt retaining walls, and the retaining walls are constructed in the deposition zone with gently sloping terrain, $W_{\text {deposit }}$ can be estimated by the following commonly used equation (Jiang 2018).

$$
W_{\text {deposit }}=\frac{H_{d}^{2}}{I} B_{d}
$$

where $H_{d}$ and $B_{d}$ are the effective height (m) and length (m) of the retaining wall, respectively.

\section{Compatibility of Engineering Structures with the Landscape and Ecosystems}

In general, debris flow control projects should be coordinated with the local landscape and ecosystem, especially in scenic areas (Cui et al., 2003; Wu and Feng 2006). To achieve this goal, the following aspects were considered in this study: 1) Optimization of the type and size of the engineering structure: Engineering structure with optimized type should be built to improve the disaster reduction effect of debris flow. Such as, slit dam and filtering dam should be built to effectively block wood debris and reduce water pollution respectively in scenic areas (Cui et al., 2007). Engineering structure with optimized size should be built to maximize the economic benefit and reduce the damage to the ecological environment due to construction. 2) Aesthetic considerations for the engineering structure: As far as possible, the engineering structure should be built out of sight of visitors to reduce the influence of the engineering structure on the aesthetic value of the scenic spot. Where this is not possible, local trees, shrubs, and grass should be transplanted to conceal the structure, and the structure should be spray painted using a color that blends well with that of the surrounding environment. 3) Suitable building materials: Local materials should be used to construct the engineering structures to avoid the influence of foreign materials on ecological resources, such as the pollution of local water bodies.

\section{RESULTS AND DISCUSSION}

\section{Application of the Planning Method for the Xiajijie Lake, Zhuozhui, Pingshitou, Xuan, and West-Zhuozhui Debris Flow Gullies}

Based on the basic information of Jiuzhaigou Valley, the experimental zone is determined using the method described in Delimiting the Area for the Construction of Debris Flow Control Projects section (Figure 10). According to the gully and distribution characteristics of loose material, the Xiajijie Lake, Zhuozhui, Pingshitou, Xuan, and West-Zhuozhui debris flow gullies can be divided into formation, transport, and deposition zones. The corresponding elevation coordinates are shown in Table 2. Debris flow control projects can be constructed in the area of overlap between the experimental zone of the scenic area and the transport and deposition zones of a debris flow gully. The elevations of the construction areas of the Xiajijie Lake, Zhuozhui, Pingshitou, Xuan, and West-Zhuozhui debris flow control projects are 2800-2620, 3025-2882, 2230-2100, 2830-2625, and $3040-2831 \mathrm{~m}$ asl, respectively (Table 2).

Based on field investigations and measured topographical data, the following debris flow control measures are adopted for Xiajijie Lake Gully, Zhuozhui Gully, Pingshitou Gully, Xuan Gully, and West-Zhuozhui Gully based on the considerations

TABLE 2 | Topographic conditions of debris flow gullies.

\section{Parameters}

Basin area $\left(\mathrm{km}^{2}\right)$

Main gully length $(\mathrm{km})$

Average gully gradient (\%o)

Highest elevation (m)

Lowest elevation (m)

Formation zone (m)

Transport zone $(\mathrm{m})$

Deposition zone $(\mathrm{m})$

Experimental zone $(\mathrm{m})$

Construction area of debris flow control projects (m)

Whether the debris flow gully mouths exhibited conditions conducive to

deposit stopping

$\begin{array}{cc}\begin{array}{c}\text { Xiajijie Lake } \\ \text { Gully }\end{array} & \begin{array}{c}\text { Zhuozhui } \\ \text { Gully }\end{array} \\ 1.87 & 4.14 \\ 2.36 & 3.3 \\ 593 & 386 \\ 4,120 & 4,492 \\ 2,620 & 2,882 \\ 4,120-2,960 & 4,492-3,925 \\ 2,960-2,660 & 3,925-3,015 \\ 2,660-2,620 & 3,015-2,882 \\ <2,800 & <3,025 \\ 2,800-2,620 & 3,025-2,882 \\ \text { No } & \text { Yes }\end{array}$

$\begin{gathered}\text { Pingshitou } \\ \text { Gully }\end{gathered}$
0.1
0.9
775
2,970
2,100
$2,970-2,600$
$2,600-2,115$
$2,115-2,100$
$<2,230$
$2,230-2,100$
No

Xuan Gully

0.56
1.05
795
3,805
2,625
$3,805-2,850$
$2,850-2,650$
$2,650-2,625$
$<2,830$
$2,830-2,625$
No

West-Zhuozhui Gully

1.33

1.77

517

3,993

2,831

3,993-3,317

3,317-2,894

2,894-2,831 $<3,040$

3,040-2,831

Yes 
described in Obtaining Topographic Conditions and Constructing Debris Flow Control Projects section. 1). After the September 25, 2017 and June 21, 2019 debris flows, large amounts of loose material were transported to the main gully mouth of Xiajijie Lake Gully. The main gully mouth does not exhibit conditions conducive to deposit stopping, and the transport zone of the gully within the construction area does not exhibit conditions conducive to blocking. Therefore, only the "drainage + deposit stopping" control mode can be adopted to treat the debris flow gully. 2) There is a large accumulation fan at the mouth of Zhuozhui Gully, which has the area required for a deposit stopping project. Gully erosion in the construction area of the debris flow control project is not serious, and the "deposit stopping" control mode can be implemented to manage debris flow disasters in Zhuozhui Gully. 3) The accumulation fan in Pingshitou Gully is small, and a scenic road has been constructed on the accumulation fan, which does not exhibit conditions conducive to deposit stopping. In the construction area of the debris flow control project, the channel in the transport zone is narrow and steep, and the storage capacity of check dams is limited. The dam was completely filled during the July 22, 2017 debris flow. There is a concave area to the right of the main gully mouth of Pingshitou Gully that exhibits conditions conducive to the construction of a retaining wall. Thus, the "drainage + deposit stopping" control mode can be adopted. The drainage channel should be constructed in the transport zone in the construction area of the debris flow control project to divert the debris flow material to the concave area, and the debris flow material should be intercepted using a retaining wall. 4) The accumulation fan at the mouth of Xuan Gully is small, and the scenic road threatened by debris flows passes the top of the accumulation fan; thus, there is not enough space for a deposit stopping project. Moreover, the transport zone of the gully does not exhibit conditions conducive to the construction of engineering structures such as check dams to intercept and hold debris flow material. Therefore, drainage projects can be constructed in the transport zone of the debris flow gully to drain the debris flow material to the concave gully mouth, and a deposit stopping project can be constructed to intercept the material. 5) The accumulation fan at the mouth of the debris flow gully in the West-Zhuozhui area is large and exhibits conditions suitable for deposit stopping. Furthermore, severe erosion occurs in the transport zone of the gully, so the "blocking + deposit stopping measures" control mode should be adopted to mitigate debris flow disasters.

Based on Eqs 1-11 in Parameter Calculation section, the $W_{d f}$ values in Xiajijie Lake Gully, Zhuozhui Gully, Pingshitou Gully, Xuan Gully, and West-Zhuozhui Gully were calculated as $2.78 \times$ $10^{4}, 2.06 \times 10^{4}, 0.228 \times 10^{4}, 0.673 \times 10^{4}$, and $0.993 \times 10^{4} \mathrm{~m}^{3}$, respectively (Table 3). Based on the control measures proposed above, the design parameters of debris flow control projects in Xiajijie Lake Gully, Zhuozhui Gully, Pingshitou Gully, Xuan Gully, and West-Zhuozhui Gully were calculated using Eqs 12-16. The specific parameters are as follows: 1) The construction of a drainage channel with a cross-sectional area of $6.0 \mathrm{~m}^{2}$ is planned in the transport zone of Xiajijie Lake Gully (Figure 4). The designed peak discharge of debris flow in the drainage channel is $61.18 \mathrm{~m}^{3} / \mathrm{s}$, which exceeds the peak discharge of debris flow $\left(58.55 \mathrm{~m}^{3} / \mathrm{s}\right)$ under the design standard adopted. Thus, the drainage channel satisfies the $Q_{\text {drainage }}>Q_{d f}$ criterion. The construction of a retaining wall with a length of $80 \mathrm{~m}$ and a height of $7 \mathrm{~m}$ is planned in the concave area to the left of Xiajijie Lake Gully (Figure 4 ). The designed storage capacity of the retaining wall is $3.01 \times 10^{4} \mathrm{~m}^{3}$, which is greater than the total amount of debris flow material that is projected to rush out $(2.78 \times$ $10^{4} \mathrm{~m}^{3}$ ) under the design standard adopted. Thus, it satisfies the $W_{\text {deposit }}>W_{d f}$ criterion. 2) The height of the original retaining wall in Zhuozhui Gully is low. The construction of a retaining wall with a length of $70 \mathrm{~m}$ and a height of $6 \mathrm{~m}$ is planned (Figure 5A). The designed storage capacity of the retaining wall is $2.1 \times 10^{4} \mathrm{~m}^{3} / \mathrm{s}$, which is greater than the total amount of debris flow material projected to rush out $\left(2.06 \times 10^{4} \mathrm{~m}^{3}\right)$ under the design standard adopted. Thus, it satisfies the $W_{\text {deposit }}>W_{d f}$ criterion. 3) The construction of a drainage channel with a cross-sectional area of $2.4 \mathrm{~m}^{2}$ is planned in the transport zone of Pingshitou Gully (Figure 6). The designed peak discharge of debris flow in the drainage channel is $16.95 \mathrm{~m}^{3} / \mathrm{s}$, which exceeds the peak discharge of debris flow $\left(3.61 \mathrm{~m}^{3} / \mathrm{s}\right)$ under the design standard adopted. Thus, it satisfies the $Q_{\text {drainage }}>Q_{d f}$ criterion. The construction of a retaining wall with a length of $30 \mathrm{~m}$ and a height of $4 \mathrm{~m}$ is planned in the concave area to the right of Pingshitou Gully (Figure 6). The designed storage capacity of the retaining wall is $0.32 \times 10^{4} \mathrm{~m}^{3}$, which is greater than the total amount of debris flow material that is projected to rush out $\left(0.228 \times 10^{4} \mathrm{~m}^{3}\right)$ under the design standard adopted. Thus, it satisfies the $W_{\text {deposit }}>W_{d f}$ criterion. 4) The construction of a drainage channel with a cross-sectional area of $3.0 \mathrm{~m}^{2}$ is planned in Xuan Gully (Figure 7). The designed peak discharge of debris flow in the drainage channel is $32.01 \mathrm{~m}^{3} / \mathrm{s}$, which exceeds the peak drainage of debris flow $\left(16.99 \mathrm{~m}^{3} / \mathrm{s}\right)$ under the design standard adopted. Thus, it satisfies the $Q_{\text {drainage }}>Q_{d f}$ criterion. The height of the existing retaining wall is low and the storage capacity is small. The construction of a retaining wall with a length of $40.0 \mathrm{~m}$ and a height of $3.0 \mathrm{~m}$ is planned. The designed storage capacity is $0.72 \times 10^{4} \mathrm{~m}^{3}$, which exceeds the total amount of debris flow material that is projected to rush out $\left(0.673 \times 10^{4} \mathrm{~m}^{3}\right)$ under the design standard adopted. Thus, it satisfies the $W_{\text {deposit }}>$ $W_{d f}$ criterion. 5) The construction of a check dam with a height of $4 \mathrm{~m}$ and a length of $20 \mathrm{~m}$ is proposed in the transport zone of WestZhuozhui Gully (Figure 8). The designed storage capacity of the check dam is $0.176 \times 10^{4} \mathrm{~m}^{3}$. At the mouth of the main gully $(2,850 \mathrm{~m}$ asl $)$, the construction of a retaining wall with a length of $60 \mathrm{~m}$ and a height of $4.0 \mathrm{~m}$ is proposed (Figure 8). The storage capacity of the proposed retaining wall is $0.87 \times 10^{4} \mathrm{~m}^{3}$, which satisfies the $W_{\text {block }}+W_{\text {deposit }}>W_{d f}$ criterion.

As discussed in Compatibility of Engineering Structures with the Landscape and Ecosystems section, the proposed control engineering structure should be coordinated with the natural landscape and ecological environment. Thus, the following measures should be adopted: 1) In Xiajijie Lake Gully, the planned retaining wall is located at the mouth of the gully, where vegetation is sparse. Therefore, construction will cause minimal damage to the vegetation in the scenic spot. However, the retaining wall is only $5 \mathrm{~m}$ away from the scenic road, and spruce, alpine willow shrubs, and a fire grass meadow should be transplanted to conceal it. 2) The planned retaining wall in the 
TABLE 3 | Parameter calculation results using the method in Engineering Planning Method for Debris Flow Disasters in Scenic Areas section.

\begin{tabular}{|c|c|c|c|c|c|c|c|}
\hline \multirow[t]{2}{*}{ Calculation content } & \multirow[t]{2}{*}{ Parameters } & \multirow[t]{2}{*}{ Unit } & \multicolumn{5}{|c|}{ Debris flow gullies } \\
\hline & & & $\begin{array}{l}\text { Xiajijie Lake } \\
\text { Gully }\end{array}$ & $\begin{array}{l}\text { Zhuozhui } \\
\text { Gully }\end{array}$ & $\begin{array}{l}\text { Pingshitou } \\
\text { Gully }\end{array}$ & $\begin{array}{l}\text { Xuan } \\
\text { Gully }\end{array}$ & $\begin{array}{l}\text { West-Zhuozhui } \\
\text { Gully }\end{array}$ \\
\hline \multirow[t]{15}{*}{ Flood peak discharge } & $\theta$ & - & 2.40 & 3.18 & 1.74 & 1.31 & 2.05 \\
\hline & $m$ & - & 0.26 & 0.28 & 0.25 & 0.23 & 0.26 \\
\hline & $H_{1 / 6}$ & $\mathrm{~mm}$ & 7.8 & 7.8 & 7.8 & 7.8 & 7.8 \\
\hline & $H_{1}$ & $\mathrm{~mm}$ & 15 & 15 & 15 & 15 & 15 \\
\hline & $H_{6}$ & $\mathrm{~mm}$ & 25 & 25 & 25 & 25 & 25 \\
\hline & $K_{1 / 6}$ & - & 2.76 & 2.76 & 2.76 & 2.76 & 2.76 \\
\hline & $K_{1}$ & - & 2.58 & 2.58 & 2.58 & 2.58 & 2.58 \\
\hline & $K_{6}$ & - & 2.42 & 2.42 & 2.42 & 2.42 & 2.42 \\
\hline & $K_{P}$ & - & 1.56 & 1.56 & 1.56 & 1.56 & 1.56 \\
\hline & $n$ & - & 0.75 & 0.75 & 0.75 & 0.67 & 0.75 \\
\hline & $\mu$ & $\mathrm{mm} / \mathrm{h}$ & 4.99 & 4.29 & 8.70 & 6.27 & 5.32 \\
\hline & $t_{0}$ & $\mathrm{~h}$ & 1.51 & 1.98 & 1.10 & 0.84 & 1.29 \\
\hline & $\varphi$ & - & 0.81 & 0.80 & 0.73 & 0.84 & 0.82 \\
\hline & $t$ & h & 1.61 & 2.13 & 1.21 & 0.88 & 1.38 \\
\hline & $Q_{f}$ & $\mathrm{~m}^{3} / \mathrm{s}$ & 11.36 & 20.13 & 0.69 & 5.53 & 9.20 \\
\hline \multirow[t]{5}{*}{ Debris flow peak discharge } & $\gamma_{d f}$ & $\mathrm{t} / \mathrm{m}^{3}$ & 1.93 & 1.68 & 1.71 & 1.63 & 1.73 \\
\hline & $D_{d f}$ & - & 2.25 & 1.90 & 3.00 & 1.90 & 1.90 \\
\hline & $Q_{d f}$ & $\mathrm{~m}^{3} / \mathrm{s}$ & 58.55 & 65.05 & 3.61 & 16.99 & 31.33 \\
\hline & $T_{d f}$ & s & 1800 & 1,200 & 2,400 & 1,500 & 1,200 \\
\hline & $W_{d f}$ & $m^{3}$ & $2.78 \times 10^{4}$ & $2.06 \times 10^{4}$ & $0.228 \times 10^{4}$ & $\begin{array}{r}0.673 \\
\times 10^{4}\end{array}$ & $0.993 \times 10^{4}$ \\
\hline \multirow{5}{*}{$\begin{array}{l}\text { Debris flow peak discharge by drainage channel } \\
\left(Q_{\text {drainage }}\right)\end{array}$} & Adrainage & $\mathrm{m}^{2}$ & 6.0 & - & 2.4 & 3.0 & - \\
\hline & $n_{\text {drainage }}$ & - & 0.04 & - & 0.04 & 0.04 & - \\
\hline & $R_{d f}$ & $\mathrm{~m}$ & 0.81 & - & 0.52 & 0.60 & - \\
\hline & $I_{\text {drainage }}$ & - & 0.22 & - & 0.19 & 0.36 & - \\
\hline & $Q_{\text {drainage }}$ & $\mathrm{m}^{3} / \mathrm{s}$ & 61.18 & - & 16.95 & 32.01 & - \\
\hline \multirow{5}{*}{$\begin{array}{l}\text { Volume of debris flow solid material trapped by blocking } \\
\text { measures }\left(W_{\text {block }}\right)\end{array}$} & $H_{b}$ & $\mathrm{~m}$ & - & - & - & - & 4 \\
\hline & 1 & - & - & - & - & - & 0.21 \\
\hline & $\alpha$ & degrees & - & - & - & - & 33 \\
\hline & $b$ & m & - & - & - & - & 20 \\
\hline & $W_{\text {block }}$ & $m^{3}$ & - & - & - & - & $0.176 \times 10^{4}$ \\
\hline \multirow{4}{*}{$\begin{array}{l}\text { Volume of debris flow solid material trapped by deposit } \\
\text { stopping measures }\left(W_{\text {deposit }}\right)\end{array}$} & $H_{d}$ & $\mathrm{~mm}$ & 7 & 6 & 4 & 3 & 4 \\
\hline & $B_{d}$ & $\mathrm{~m}$ & 80 & 70 & 30 & 40 & 60 \\
\hline & 1 & - & 0.13 & 0.12 & 0.15 & 0.05 & 0.11 \\
\hline & $W_{\text {deposit }}$ & $\mathrm{m}^{3}$ & $3.01 \times 10^{4}$ & $2.1 \times 10^{4}$ & $0.32 \times 10^{4}$ & $\begin{array}{r}0.72 \\
\times 10^{4}\end{array}$ & $0.87 \times 10^{4}$ \\
\hline
\end{tabular}

deposition zone of Zhuozhui Gully is approximately $100 \mathrm{~m}$ away from the scenic road, which is far beyond the visual range of tourists. Thus, there is no need for transplantation of vegetation to conceal the retaining wall, and the outside of the retaining wall can be painted so that it blends into the surrounding environment. 3) The proposed retaining walls at the mouths of Pingshitou Gully, Xuan Gully, and West-Zhuozhui Gully are low. Only Salix alpina shrubs need to be transplanted to conceal the retaining wall, and the outside of the retaining wall should be painted so that it blends into the surrounding environment.

\section{Control Modes of Debris Flow Disasters in Jiuzhaigou Valley}

Based on the control engineering planning method proposed herein, the control modes for debris flow gullies in scenic areas can be divided into four categories (Figure 11). 1) For debris flow gullies that demonstrate severe erosion and conditions conducive to deposit stopping, blocking projects should be constructed in the transport zone. This control mode can realize the objective of retaining and stabilizing loose material and reduce the scale of debris flows and the damage they cause. Deposit stopping projects should then be constructed in the deposition zone within the construction area of debris flow control projects. This can stop debris flow material and reduce damage to vulnerable downstream structures (Figure 11A). 2) For debris flow gullies that do not demonstrate severe erosion and exhibit conditions conducive to deposit stopping, only deposit stopping projects should be constructed in the deposition zone within the construction area of debris flow control projects (Figure 11B). 3) In debris flow gullies that do not exhibit conditions conducive to deposit stopping but in which the channels in the transport zone exhibit material conditions conducive to debris flow retention, only blocking projects should be constructed in the transport zone within the construction area of debris flow control projects. This can realize the effective interception of debris flow material and reduce damage to 

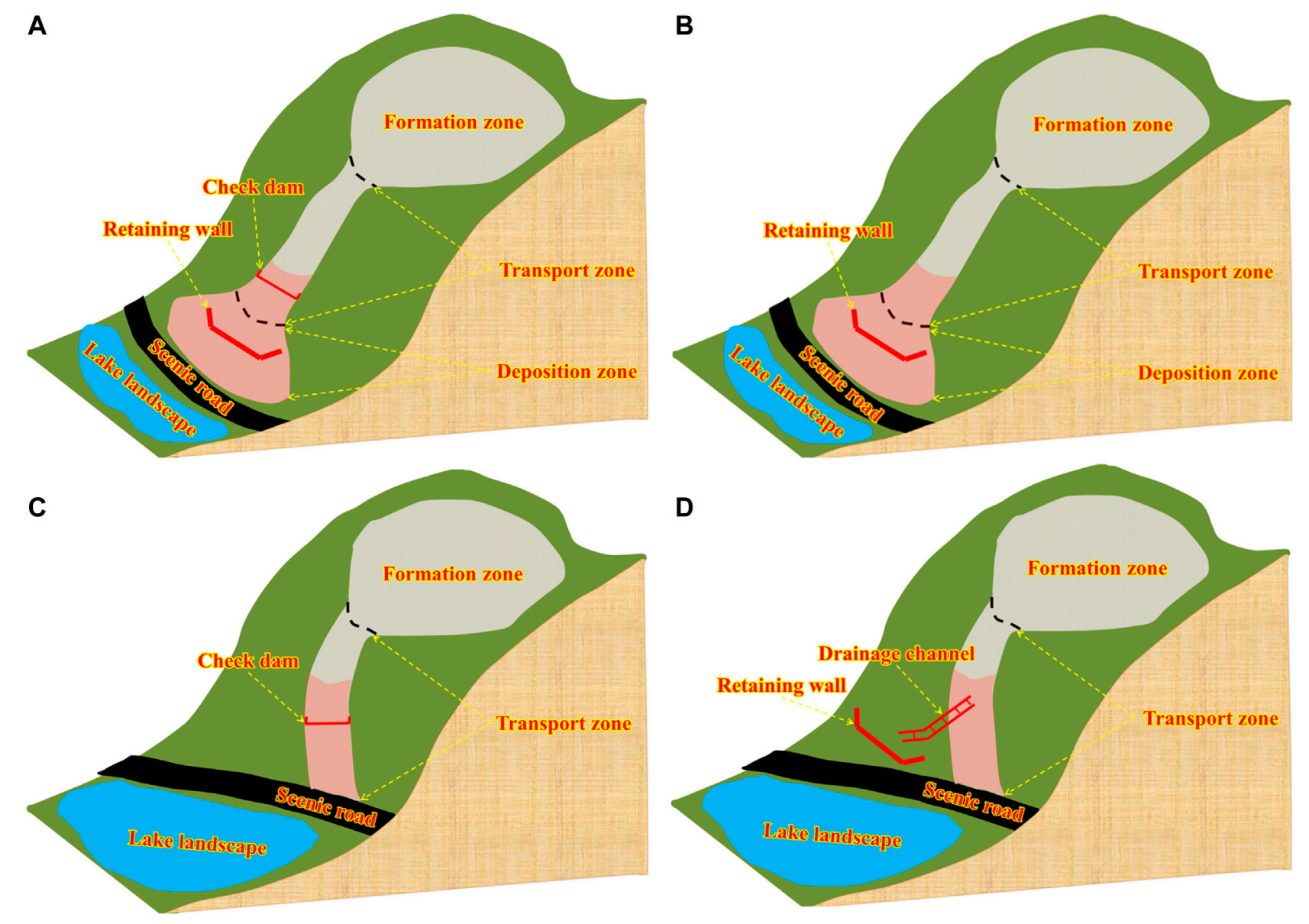

FIGURE 11 | Control modes of debris flow disasters in scenic areas. (A) Engineering countermeasures with blocking and deposit stopping measures. (B) Engineering countermeasures with deposit stopping measures. (C) Engineering countermeasures with blocking measures. (D) Engineering countermeasures with drainage and deposit stopping measures. The light red shaded regions represent the area for the construction of debris flow control projects, which can be obtained through the method in Delimiting the Area for the Construction of Debris Flow Control Projects section.

downstream objects and structures (Figure 11C). 4) For debris flow gullies that do not exhibit conditions conducive to deposit stopping and for which the channel in the transport zone does not exhibit material conditions conducive to debris flow retention, drainage projects should be constructed in the transport zone of the debris flow gully to divert the debris flow material into recesses on both sides of the gully, and deposit stopping projects should be constructed to retain the diverted material (Figure 11D).

Based on the foregoing analysis, the planning method proposed in this study is used to plan engineering countermeasures for debris flow gullies in scenic areas with severe hazards, and the control mode used in various debris flow gullies is discussed (Table 4). According to the analysis results, the post-earthquake control modes for the debris flow gullies in Xiajijie Lake, Zhuozhui, Pingshitou, Xuan, and WestZhuozhui are "drainage + deposit stopping," "deposit stopping," "drainage + deposit stopping," "drainage + deposit stopping," and "blocking + deposit stopping," respectively. Field investigations indicate that the existing control modes for Xiajijie Lake Gully and Pingshitou Gully have not been effective, and the engineering structures have been partially damaged. Therefore, the results of this study can provide a reference for the improvement of subsequent management project schemes, so as to mitigate post-earthquake debris flow disasters in scenic areas under the condition of future climate change.

\section{Differences in the Management of Debris Flows in Scenic and Mountainous Urban Areas}

The management of debris flow disasters has attracted widespread attention in mountainous urban areas. For example, by comparing approaches to debris flow control in several countries in the world (including France, Italy, Austria, Switzerland, Japan, and North America), an approach involving the construction of check dams to comprehensively manage debris flow disasters at the basin scale was proposed. These check dams perform the functions of bed stabilization, hillslope consolidation, slope gradient reduction, sediment retention, and sediment transport regulation (Piton et al., 2016). Several studies on the types, regulation 
TABLE 4 | Debris flow control mode in Jiuzhaigou Valley.

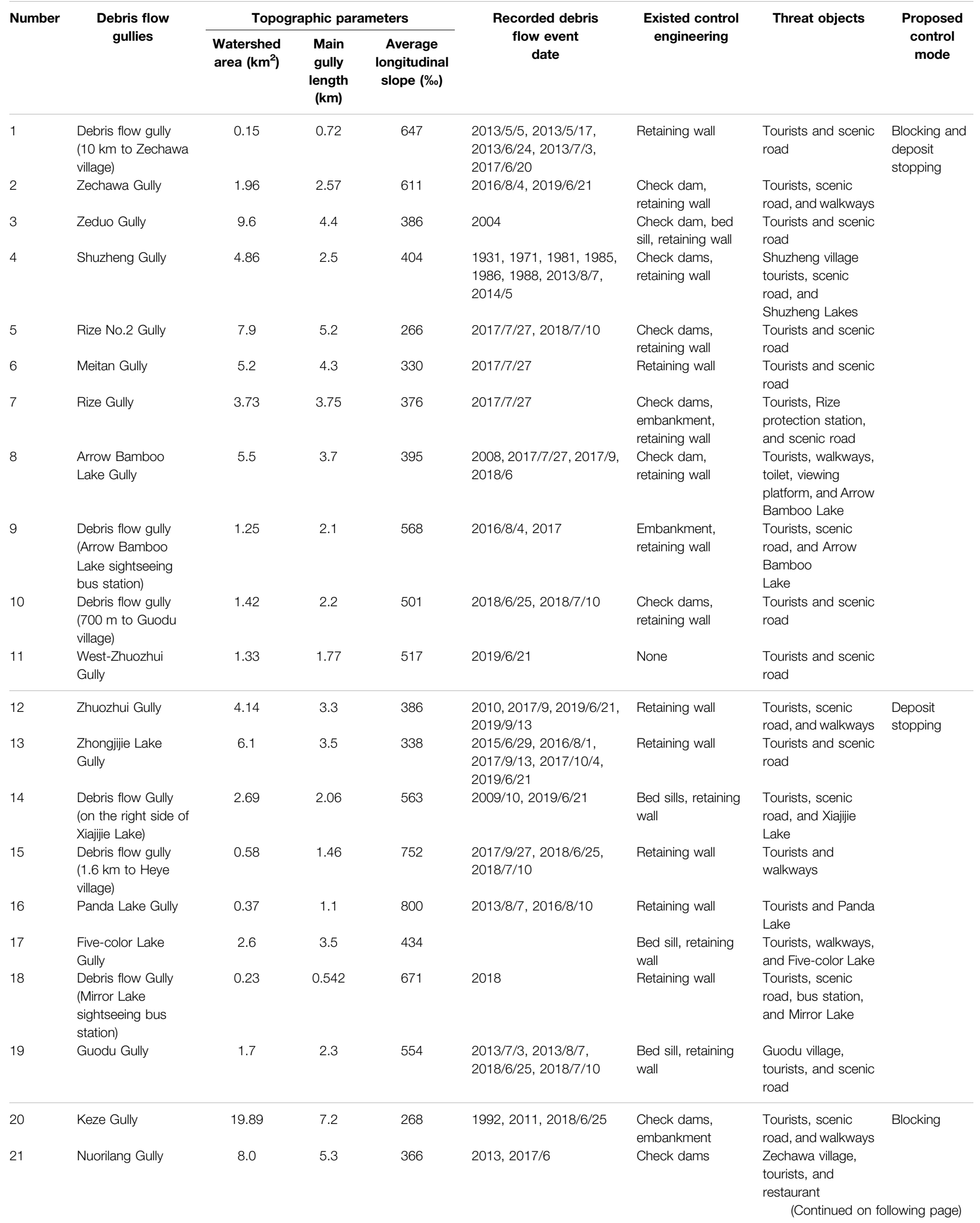


TABLE 4 | (Continued) Debris flow control mode in Jiuzhaigou Valley.

\begin{tabular}{|c|c|c|c|c|c|c|c|c|}
\hline \multirow[t]{2}{*}{ Number } & \multirow{2}{*}{$\begin{array}{l}\text { Debris flow } \\
\text { gullies }\end{array}$} & \multicolumn{3}{|c|}{ Topographic parameters } & \multirow{2}{*}{$\begin{array}{l}\text { Recorded debris } \\
\text { flow event } \\
\text { date }\end{array}$} & \multirow{2}{*}{$\begin{array}{l}\text { Existed control } \\
\text { engineering }\end{array}$} & \multirow[t]{2}{*}{ Threat objects } & \multirow{2}{*}{$\begin{array}{c}\text { Proposed } \\
\text { control } \\
\text { mode }\end{array}$} \\
\hline & & $\begin{array}{l}\text { Watershed } \\
\text { area }\left(\mathbf{k m}^{2}\right)\end{array}$ & $\begin{array}{l}\text { Main } \\
\text { gully } \\
\text { length } \\
(\mathbf{k m})\end{array}$ & $\begin{array}{c}\text { Average } \\
\text { longitudinal } \\
\text { slope (\%) }\end{array}$ & & & & \\
\hline 22 & Heye Gully & 25.5 & 8.0 & 186 & $\begin{array}{l}\text { 1948, 2018/6/25, 2018/ } \\
7 / 10\end{array}$ & Check dams & $\begin{array}{l}\text { Heye village, } \\
\text { tourists, scenic } \\
\text { road, and } \\
\text { Penjingtan } \\
\text { attractions }\end{array}$ & \\
\hline 23 & $\begin{array}{l}\text { Debris flow gully } \\
\text { (community group } \\
1 \text { of Heye village) }\end{array}$ & 3 & 3.3 & 262 & $\begin{array}{l}\text { 1948, 2018/6/25, 2018/ } \\
7 / 10\end{array}$ & $\begin{array}{l}\text { Check dams, bed } \\
\text { sill, embankment }\end{array}$ & Heye village & \\
\hline 24 & $\begin{array}{l}\text { Debris flow gully } \\
\text { (opposite Swan } \\
\text { Lake sightseeing } \\
\text { bus station) }\end{array}$ & 0.3 & 1.5 & 597 & & Check dams & Tourists & \\
\hline 26 & Danzu Gully & 73.88 & 16.2 & 87 & 1984 & Check dams & Mirror Lake & \\
\hline 27 & Mirror Gully & 2.55 & 2.9 & 441 & 2018 & Check dams & $\begin{array}{l}\text { Tourists, scenic } \\
\text { road, and walkways }\end{array}$ & \\
\hline 28 & Nadi Gully & 4.68 & 3.8 & 544 & $\begin{array}{l}\text { 2011/9/5, 2015/6/1, } \\
\text { 2017/9/27 }\end{array}$ & $\begin{array}{l}\text { Check dams, } \\
\text { embankment }\end{array}$ & $\begin{array}{l}\text { Burning incense } \\
\text { attractions and } \\
\text { scenic road }\end{array}$ & \\
\hline 29 & Rexi Gully & 8.24 & 5.81 & 372 & 2018/6/25, 2018/7/10 & $\begin{array}{l}\text { Check dams, bed } \\
\text { sill, embankment }\end{array}$ & $\begin{array}{l}\text { Rexi village and } \\
\text { tourists }\end{array}$ & \\
\hline 30 & Xuan Gully & 0.56 & 1.05 & 795 & $\begin{array}{l}\text { 2013/7/3, 2013/7/28, } \\
\text { 2013/8/3, 2013/8/7 } \\
\text { 2015/6/28, 2019/6/21 }\end{array}$ & $\begin{array}{l}\text { Drainage channel, } \\
\text { retaining wall }\end{array}$ & $\begin{array}{l}\text { Tourists, scenic } \\
\text { road, and Xiajijie } \\
\text { Lake }\end{array}$ & $\begin{array}{l}\text { Drainage and } \\
\text { deposit } \\
\text { stopping }\end{array}$ \\
\hline 31 & Xiaijije Lake Gully & 1.87 & 2.36 & 593 & $\begin{array}{l}\text { 1976, 1983, 1984, 2012/ } \\
7 / 21,2013 / 7 / 3,2013 / 7 / \\
28,2017 / 9 / 9,2017 / 9 / 14, \\
2017 / 9 / 24,2017 / 9 / 25 \\
2019 / 6 / 21\end{array}$ & $\begin{array}{l}\text { Check dams, } \\
\text { drainage channel, } \\
\text { retaining wall }\end{array}$ & $\begin{array}{l}\text { Tourists, scenic } \\
\text { road, walkways, } \\
\text { and Xiajijie Lake }\end{array}$ & \\
\hline
\end{tabular}

Note: The occurrence time of the recorded debris flow events is taken from the annual disaster survey report of Jiuzhaigou Valley and the investigation report for the control of debris flow disasters in Jiuzhaigou Valley. The locations of all debris flow gullies in the table have been marked in Figure 10.

mechanisms, and disaster mitigation effects of check dams have been conducted (DeWolfe et al., 2008; Piton and Recking 2016; Cucchiaro et al., 2019a; Cucchiaro et al., 2019b; Bernard et al., 2019). In China, it is more common to implement management measures for debris flow gullies at the regional scale. The "stabilization + blocking + drainage + deposit stopping" control modes are adopted in the formation, transport, and deposition zones, respectively, with blocking measures being the most commonly implemented measures (Cui and Lin, 2013; Liu et al., 2017). This control approach is similar to that employed in Japan (Ikeya 1989; Takahashi 2007). However, after the Wenchuan earthquake, the frequency and scale of occurrence of debris flow disasters have increased significantly, and existing engineering projects have not been able to effectively mitigate these disasters. Moreover, a large number of engineering projects, particularly check dams, have been seriously damaged (Wang 2013; Chen et al., 2015). Therefore, many scholars have proposed a new approach for disaster mitigation. The proposed approach, which has proven to be effective, prioritizes the use of drainage measures, and makes full use of the transport capacity of the main river to discharge debris flow material to downstream rivers (Chen et al., 2015; Xiong et al., 2016).

The aforementioned studies have mainly focused on typical mountainous urban areas, and the proposed control methods cannot be applied to the mitigation of debris flows in the scenic area investigated herein. The reasons for this are as follows: 1) Owing to topographic conditions, no large river exists in the scenic area, and the water bodies (such as Long Lake and Nuorilang Waterfall in Jiuzhaigou Valley) distributed throughout the scenic area are important landscape resources that do not exhibit conditions conducive to the discharge of debris flow material. Thus, the control method proposed by Chen et al. (2015) is not applicable in this area. 2) Compared with the debris flow control projects in typical mountainous urban areas, debris flow control projects in scenic areas can only be implemented in the experimental zones owing to restrictions related to the functional zoning of nature reserves; it is impossible to implement large-scale engineering projects for debris flow control at the watershed scale. Therefore, the control method proposed by Piton et al. (2016) is 
inappropriate for this area. The scale of debris flow disasters in scenic areas is smaller than that of disasters in typical mountainous urban areas owing to the lush vegetation and the smaller watershed area of debris flow gullies in scenic areas. Thus, the construction of small projects in the transport and deposition zones can meet the design requirements. Furthermore, these small projects are easy to integrate with the landscape and do not significantly damage the environment in scenic areas.

\section{Limitations of the Engineering Planning Method}

This study proposed an engineering planning method for debris flow control in scenic areas, with the aim of providing guidance for relevant stakeholders to rapidly formulate control engineering plans for different debris flow gullies in scenic areas after debris flow disasters, especially mass debris flow disasters after earthquakes. However, the following limitations should be considered when this planning method is used for debris flow control engineering in scenic areas. 1) Owing to the difference of topographic conditions and threatened objects, the applicability of this planning method to debris flow control engineering planning in other scenic areas requires further verification. 2) This planning method adopts a large number of equations recommended by the code to calculate the design parameters of debris flow control engineering projects. These equations can be used to obtain the calculated values based on a small number of parameters, so they are widely used. However, the values of relevant parameters vary in different areas, so local norms should be consulted when this planning method is used to plan debris flow control projects in other scenic areas. 3) In this study, only engineering measures are considered for the control of debris flow in scenic areas. Ecological measures should also be considered for the treatment of debris flow in scenic areas. This aspect can be explored in future work.

\section{CONCLUSION}

Based on field investigations of existing debris flow control projects in scenic areas, a planning method for debris flow control projects in scenic areas is proposed. The planning method first involves the determination of the scope of the area in which the control project can be implemented, based on the requirements related to the functional zoning of the scenic area. Then, based on the objects threatened by debris flows and the topographical features of debris flow gullies in the scenic area, the "blocking + deposit stopping," "deposit stopping," "blocking," and "drainage + deposit stopping" control modes are adopted. Finally, the amount of debris flow material that can be intercepted by the engineering structure is quantified based on parameter calculations. Based on the planning method for debris flow control engineering in the scenic area, the shortcomings of the existing control engineering projects in the scenic area are discussed. For the debris flow gullies in Xiajijie Lake, Zhuozhui, Xuan, Pingshitou, and West-Zhuozhui, the "drainage + deposit stopping," "deposit stopping," "drainage + deposit stopping," "drainage + deposit stopping," and "blocking + deposit stopping" control engineering schemes are proposed, respectively. The proposed control engineering schemes meet the requirements of coordination with the landscape and ecosystem.

On this basis, the control mode of debris flow disasters in scenic areas is discussed: 1) For debris flow gullies with severe erosion and conditions that are conducive to deposit stopping, blocking projects should be constructed in the transport zone and deposit stopping projects should be constructed in the deposition zone within the construction area of debris flow control projects. 2) For debris flow gullies without severe erosion but which exhibit conditions conducive to deposit stopping, only deposit stopping projects should be constructed in the deposition zone within the construction area of debris flow control projects. 3) For debris flow gullies that do not exhibit conditions conducive to deposit stopping but for which the channel in the transport zone exhibits material conditions conducive to debris flow retention, only blocking projects should be constructed in the transport zone within the construction area of debris flow control projects. 4) For debris flow gullies that do not exhibit conditions conducive to deposit stopping and for which the channel in the transport zone does not exhibit material conditions conducive to debris flow retention, drainage projects should be constructed in the transport zone to discharge the debris flow material into the recesses on both the sides of the gully, and deposit stopping projects should be constructed to retain the diverted material. The results of this study are expected to provide a systematic control strategy for debris flow disaster management in scenic areas.

\section{DATA AVAILABILITY STATEMENT}

The original contributions presented in the study are included in the article/supplementary material, further inquiries can be directed to the corresponding author.

\section{AUTHOR CONTRIBUTIONS}

X-LG and K-TC contributed to the conceptualization, methodology, analysis and manuscript writing of the study. XQC proposed the main structure of this study and approved the final version. W-YZ and J-GC participate in field investigations and helped perform the analysis with constructive discussions.

\section{FUNDING}

This research was supported by the National Natural Science Foundation of China (Grant No. 41925030), the Open Foundation of Key Laboratory of Mountain Hazards and Earth Surface Processes, CAS and the CAS "Light of West China” Program.

\section{ACKNOWLEDGMENTS}

The authors wish to thank the Editor (Y-CT) and two reviewers for their constructive comments and engineer Jie Lang for providing some field photographs. 


\section{REFERENCES}

Bernard, M., Boreggio, M., Degetto, M., and Gregoretti, C. (2019). Model-based approach for design and performance evaluation of works controlling stony debris flows with an application to a case study at Rovina di Cancia (Venetian Dolomites, Northeast Italy). Sci. Total Environ. 688, 1373-1388. doi:10.1016/ j.scitotenv.2019.05.468

Chen, J. G., Chen, X. Q., Zhao, W. Y., and You, Y. (2018). Debris Flow Drainage Channel with Energy Dissipation Structures: Experimental Study and Engineering Application. J. Hydraulic Eng. 144. doi:10.1061/(ASCE) HY.1943-7900.0001523

Chen, K.-T., Chen, X.-Q., Hu, G.-S., Kuo, Y.-S., Huang, Y.-R., and Shieh, C.-L. (2019a). Dimensionless Assessment Method of Landslide Dam Formation Caused by Tributary Debris Flow Events. Geofluids 2019, 1-14. doi:10.1155/ 2019/7083058

Chen, K.-T., Chen, X.-Q., Niu, Z.-P., and Guo, X.-J. (2019b). Early Identification of River Blocking Induced by Tributary Debris Flow Based on Dimensionless Volume index. Landslides 16, 2335-2352. doi:10.1007/s10346-019-01221-8

Chen, K.-T., Lin, C.-H., Chen, X.-Q., Hu, G.-S., Guo, X.-J., and Shieh, C.-L. (2018). An Assessment Method for Debris Flow Dam Formation in Taiwan. Earth Sci. Res. J. 22, 37-43. doi:10.15446/esrj.v22n1.62389

Chen, M.-l., Hu, G.-s., Chen, N.-s., Zhao, C.-y., Zhao, S.-j., and Han, D.-w. (2016). Valuation of Debris Flow Mitigation Measures in Tourist Towns: a Case Study on Hongchun Gully in Southwest China. J. Mt. Sci. 13, 1867-1879. doi:10.1007/ s11629-015-3759-4

Chen, X.-q., Chen, J.-g., Cui, P., You, Y., Hu, K.-h., Yang, Z.-j., et al. (2018). Assessment of Prospective Hazards Resulting from the 2017 Earthquake at the World Heritage Site Jiuzhaigou Valley, Sichuan, China. J. Mt. Sci. 15, 779-792. doi:10.1007/s11629-017-4785-1

Chen, X., Cui, P., You, Y., Chen, J., and Li, D. (2015). Engineering Measures for Debris Flow hazard Mitigation in the Wenchuan Earthquake Area. Eng. Geology 194, 73-85. doi:10.1016/j.enggeo.2014.10.002

China Association of Geological Hazard Prevention (2018). Specification of Design for Debris Flow Prevention. T/CAGHP 021-2018. Wuhan: China University of Geosciences Press.

Cucchiaro, S., Cavalli, M., Vericat, D., Crema, S., Llena, M., Beinat, A., et al. (2019a). Geomorphic Effectiveness of Check Dams in a Debris-Flow Catchment Using Multi-Temporal Topographic Surveys. CATENA 174, 73-83. doi:10.1016/j.catena.2018.11.004

Cucchiaro, S., Cazorzi, F., Marchi, L., Crema, S., Beinat, A., and Cavalli, M. (2019b). Multi-temporal Analysis of the Role of Check Dams in a Debris-Flow Channel: Linking Structural and Functional Connectivity. Geomorphology 345, 1-13. doi:10.1016/j.geomorph.2019.106844

Cui, G. F., Li, Z., Wang, Q. C, et al. National Standard of the People's Republic of China (2018). Technical Regulation for Nature Reserve Zoning. Beijing: Standards Press of China. GB/T 35822-2018 (In Chinese).

Cui, P., Chen, X., Liu, S., and Tang, B. (2007). Techniques of Debris Flow Prevention in National parks. Earth Sci. Front. 14, 172-177. doi:10.1016/ S1872-5791(08)60009-3

Cui, P., and Lin, Y. M. (2013). Debris-Flow Treatment: The Integration of Botanical and Geotechnical Methods. J. Resour. Ecol. 4, 97-104. doi:10.5814/j.issn.1674764x.2013.02.001

Cui, P., Liu, S. Q., Tang, B. X., and Chen, X. Q. (2003). Debris Flow Prevention Pattern in National parks-Taking the World Natural Heritage Jiuzhaigou as an Example. Sci. China Ser. E 46, 1-11. doi:10.1360/03ez0004

Cui, P., Zhou, G. G. D., Zhu, X. H., and Zhang, J. Q. (2013). Scale Amplification of Natural Debris Flows Caused by Cascading Landslide Dam Failures. Geomorphology 182, 173-189. doi:10.1016/j.geomorph.2012.11.009

Dahlquist, M. P., and West, A. J. (2019). Initiation and Runout of Post-Seismic Debris Flows: Insights from the 2015 Gorkha Earthquake. Geophys. Res. Lett. 46, 9658-9668. doi:10.1029/2019GL083548

DeWolfe, V. G., Santi, P. M., Ey, J., and Gartner, J. E. (2008). Effective Mitigation of Debris Flows at Lemon Dam, La Plata County, Colorado. Geomorphology 96, 366-377. doi:10.1016/j.geomorph.2007.04.008

Domènech, G., Fan, X., Scaringi, G., van Asch, T. W. J., Xu, Q., Huang, R., et al. (2019). Modelling the Role of Material Depletion, Grain Coarsening and
Revegetation in Debris Flow Occurrences after the 2008 Wenchuan Earthquake. Eng. Geology 250, 34-44. doi:10.1016/j.enggeo.2019.01.010

Faccini, Francesco, F., Piccazzo, Mauro, M., and Robbiano, Andrea, A. (2009). Valutazione della pericolosità geomorfologica da colate detritiche nel bacino idrografico di San Fruttuoso di Camogli (Parco di Portofino, Italia). Ital. J. Geosciences 128, 641-654. doi:10.3301/IJG.2009.128.3.641

Fan, R. L., Zhang, L. M., Wang, H. J., and Fan, X. M. (2018). Evolution of Debris Flow Activities in Gaojiagou Ravine during 2008-2016 after the Wenchuan Earthquake. Eng. Geology 235, 1-10. doi:10.1016/j.enggeo.2018.01.017

Fan, X., Scaringi, G., Xu, Q., Zhan, W., Dai, L., Li, Y., et al. (2018). Coseismic Landslides Triggered by the 8th August 2017 Ms 7.0 Jiuzhaigou Earthquake (Sichuan, China): Factors Controlling Their Spatial Distribution and Implications for the Seismogenic Blind Fault Identification. Landslides 15, 967-983. doi:10.1007/s10346-018-0960-X

Gong, X.-L., Chen, K.-T., Chen, X.-Q., You, Y., Chen, J.-G., Zhao, W.-Y., et al. (2020). Characteristics of a Debris Flow Disaster and its Mitigation Countermeasures in Zechawa Gully, Jiuzhaigou Valley, China. Water 12, 1256. doi:10.3390/w12051256

$\mathrm{Hu}, \mathrm{X} ., \mathrm{Hu}, \mathrm{K}$. , Tang, J., You, Y., and Wu, C. (2019). Assessment of Debris-Flow Potential Dangers in the Jiuzhaigou Valley Following the August 8, 2017, Jiuzhaigou Earthquake, Western China. Eng. Geology 256, 57-66. doi:10.1016/ j.enggeo.2019.05.004

Huang, H., Shi, S. W., Yang, S., Tian, Y., Yang, D. X., and Liu, J. K. (2020). Study on the Damage of the August 82017 Jiuzhaigou Earthquake to Debris Flow Mitigation Engineering in the national park. Chin. J. Rock Mech. Eng. 39, 1773-1786. doi:10.13722/j.cnki.jrme.2020.0099

Hungr, O., Leroueil, S., and Picarelli, L. (2014). The Varnes Classification of Landslide Types, an Update. Landslides 11, 167-194. doi:10.1007/s10346-013-0436-y

Ikeya, H. (1989). Debris Flow and its Countermeasures in Japan. Bull. Int. Assoc. Eng. Geology 40, 15-33. doi:10.1007/bf02590339

Jiang, Z. X. (2018). Practical Technology for Survey and Design of Mountain Geological Disaster Control Engineering after Earthquake. Chengdu: Southwest Jiaotong University Press.

Junichi, K., and Naoki, I. (2020). Outline of Measures for Sediment Disaster by the Sabo Department of MLIT, Japan. Landslides 17, 2503-2513. doi:10.1007/ s10346-020-01554-9

Liu, F. Z., Xu, Q., Dong, X. J., Yu, B., Frost, J. D., and Li, H. J. (2017). Design and Performance of a Novel Multi-Function Debris Flow Mitigation System in Wenjia Gully, Sichuan. Landslides 14, 2089-2104. doi:10.1007/s10346-0170849-0

Liu, J., You, Y., Chen, X., and Chen, X. (2015). Mitigation Planning Based on the Prediction of River Blocking by a Typical Large-Scale Debris Flow in the Wenchuan Earthquake Area. Landslides 13, 1231-1242. doi:10.1007/s10346015-0615-0

Liu, J., You, Y., Chen, X., Liu, J., and Chen, X. (2014). Characteristics and hazard Prediction of Large-Scale Debris Flow of Xiaojia Gully in Yingxiu Town, Sichuan Province, China. Eng. Geology 180, 55-67. doi:10.1016/j.enggeo.2014.03.017

Liu, S., Wei, L., and Hu, K. (2020). Topographical and Geological Variation of Effective Rainfall for Debris-Flow Occurrence from a Large-Scale Perspective. Geomorphology 358, 107134. doi:10.1016/j.geomorph.2020.107134

Ma, C., Wang, Y., Hu, K., Du, C., and Yang, W. (2017). Rainfall Intensity-Duration Threshold and Erosion Competence of Debris Flows in Four Areas Affected by the 2008 Wenchuan Earthquake. Geomorphology 282, 85-95. doi:10.1016/ j.geomorph.2017.01.012

Ministry of Land and Resources of the People's Republic of China (2006). Specification of Geological Investigation for Debris Flow stabilizationDZ/ T0220-2006. Beijing: Standards Press of China. (In Chinese).

Ni, H. Y., Zheng, W. M., Tie, Y. B., Su, P. C., Tang, Y. Q., Xu, R. G., et al. (2012). Formation and Characteristics of post-earthquake Debris Flow: a Case Study from Wenjia Gully in Mianzhu, Sichuan, SW China. Nat. Hazards 61, 317-335. doi:10.1007/s11069-011-9914-5

Piton, G., and Recking, A. (2016). Design of Sediment Traps with Open Check Dams. I: Hydraulic and Deposition Processes. J. Hydraul. Eng. 142. doi:10.1061/ (ASCE)HY.1943-7900.0001048

Piton, G., Carladous, S., Recking, A., Tacnet, J. M., Liébault, F., Kuss, D., et al. (2016). Why Do We Build Check Dams in Alpine Streams? an Historical Perspective from the French Experience. Earth Surf. Process. Landforms 42, 91-108. doi:10.1002/esp.3967 
Santi, P. M., deWolfe, V. G., Higgins, J. D., Cannon, S. H., and Gartner, J. E. (2008). Sources of Debris Flow Material in Burned Areas. Geomorphology 96, 310-321. doi:10.1016/j.geomorph.2007.02.022

Shieh, C. L., Chen, Y. S., Tsai, Y. J., and Wu, J. H. (2009). Variability in Rainfall Threshold for Debris Flow after the Chi-Chi Earthquake in central Taiwan, China. Int. J. Sediment Res. 24, 177-188. doi:10.1016/S1001-6279(09) 60025-1

Takahashi, T. (2007). Debris Flow Mechanics, Prediction and Countermeasures. London, UK: Taylor \& Francis Group.

Tang, C., van Asch, T. W. J., Chang, M., Chen, G. Q., Zhao, X. H., and Huang, X. C. (2012). Catastrophic Debris Flows on 13 August 2010 in the Qingping Area, Southwestern China: The Combined Effects of a strong Earthquake and Subsequent Rainstorms. Geomorphology 139-140, 559-576. doi:10.1016/ j.geomorph.2011.12.021

Van Dine, D. F. (1996). Debris Flow Control Structures for Forest Engineering. Victoria: Res. Br., B.C. Min.

Wang, G. L. (2013). Lessons Learned from Protective Measures Associated with the 2010 Zhouqu Debris Flow Disaster in China. Nat. Hazards 69, 1835-1847. doi:10.1007/s11069-013-0772-1

Wang, J.-J. (2016). Large-scale Debris Flow Disasters: hazard-risk-vulnerability Analysis Approach in Taiwan. Conservation Management Archaeological Sites 18, 449-463. doi:10.1080/13505033.2016.1290473

Wu, H.-L., and Feng, Z.-y. (2006). Ecological Engineering Methods for Soil and Water Conservation in Taiwan. Ecol. Eng. 28, 333-344. doi:10.1016/ j.ecoleng.2006.09.005

Xiong, J., Tang, C., Chen, M., Zhang, X., Shi, Q., and Gong, L. (2020). Activity Characteristics and Enlightenment of the Debris Flow Triggered by the Rainstorm on 20 August 2019 in Wenchuan County, China, Bull. Eng. Geol. Environ., 80. 873-888. doi:10.1007/s10064-020-01981-x

Xiong, M., Meng, X., Wang, S., Guo, P., Li, Y., Chen, G., et al. (2016). Effectiveness of Debris Flow Mitigation Strategies in Mountainous Regions. Prog. Phys. Geogr. Earth Environ. 40, 768-793. doi:10.1177/0309133316655304

Yu, B., Ma, Y., and Wu, Y. (2013). Case Study of a Giant Debris Flow in the Wenjia Gully, Sichuan Province, China. Nat. Hazards 65, 835-849. doi:10.1007/ s11069-012-0395-y

Zeng, Q. L., Yue, Z. Q., Yang, Z. F., and Zhang, X. J. (2009). A Case Study of LongTerm Field Performance of Check-Dams in Mitigation of Soil Erosion in
Jiangjia Stream, China. Environ. Geol. 58, 897-911. doi:10.1007/s00254-0081570-Z

Zhang, S., Zhang, L. M., and Chen, H. X. (2014). Relationships Among Three Repeated Large-Scale Debris Flows at Pubugou Ravine in the Wenchuan Earthquake Zone. Can. Geotech. J. 51, 951-965. doi:10.1139/cgj-2013-0368

Zhao, D., Qu, C., Shan, X., Gong, W., Zhang, Y., and Zhang, G. (2018). InSAR and GPS Derived Coseismic Deformation and Fault Model of the 2017 Ms7.0 Jiuzhaigou Earthquake in the Northeast Bayanhar Block. Tectonophysics 726, 86-99. doi:10.1016/j.tecto.2018.01.026

Zhao, W., You, Y., Chen, X., Liu, J., and Chen, J. (2020). Case Study on Debris-Flow hazard Mitigation at a World Natural Heritage Site, Jiuzhaigou Valley, Western China. Geomatics, Nat. Hazards Risk 11, 1782-1804. doi:10.1080/ 19475705.2020.1810784

Zhou, B. F., Li, D. J., Luo, D. F., Lv, R. R., and Yang, Q. X. (1991). Guide to Prevention of Debris Flow. Beijing: Science Press. (In Chinese).

Zhou, W., Tang, C., Van Asch, T. W. J., and Chang, M. (2016). A Rapid Method to Identify the Potential of Debris Flow Development Induced by Rainfall in the Catchments of the Wenchuan Earthquake Area. Landslides 13, 1243-1259. doi:10.1007/s10346-015-0631-0

Conflict of Interest: The authors declare that the research was conducted in the absence of any commercial or financial relationships that could be construed as a potential conflict of interest.

Publisher's Note: All claims expressed in this article are solely those of the authors and do not necessarily represent those of their affiliated organizations, or those of the publisher, the editors and the reviewers. Any product that may be evaluated in this article, or claim that may be made by its manufacturer, is not guaranteed or endorsed by the publisher.

Copyright (c) 2021 Gong, Chen, Chen, Zhao and Chen. This is an open-access article distributed under the terms of the Creative Commons Attribution License (CC BY). The use, distribution or reproduction in other forums is permitted, provided the original author(s) and the copyright owner(s) are credited and that the original publication in this journal is cited, in accordance with accepted academic practice. No use, distribution or reproduction is permitted which does not comply with these terms. 